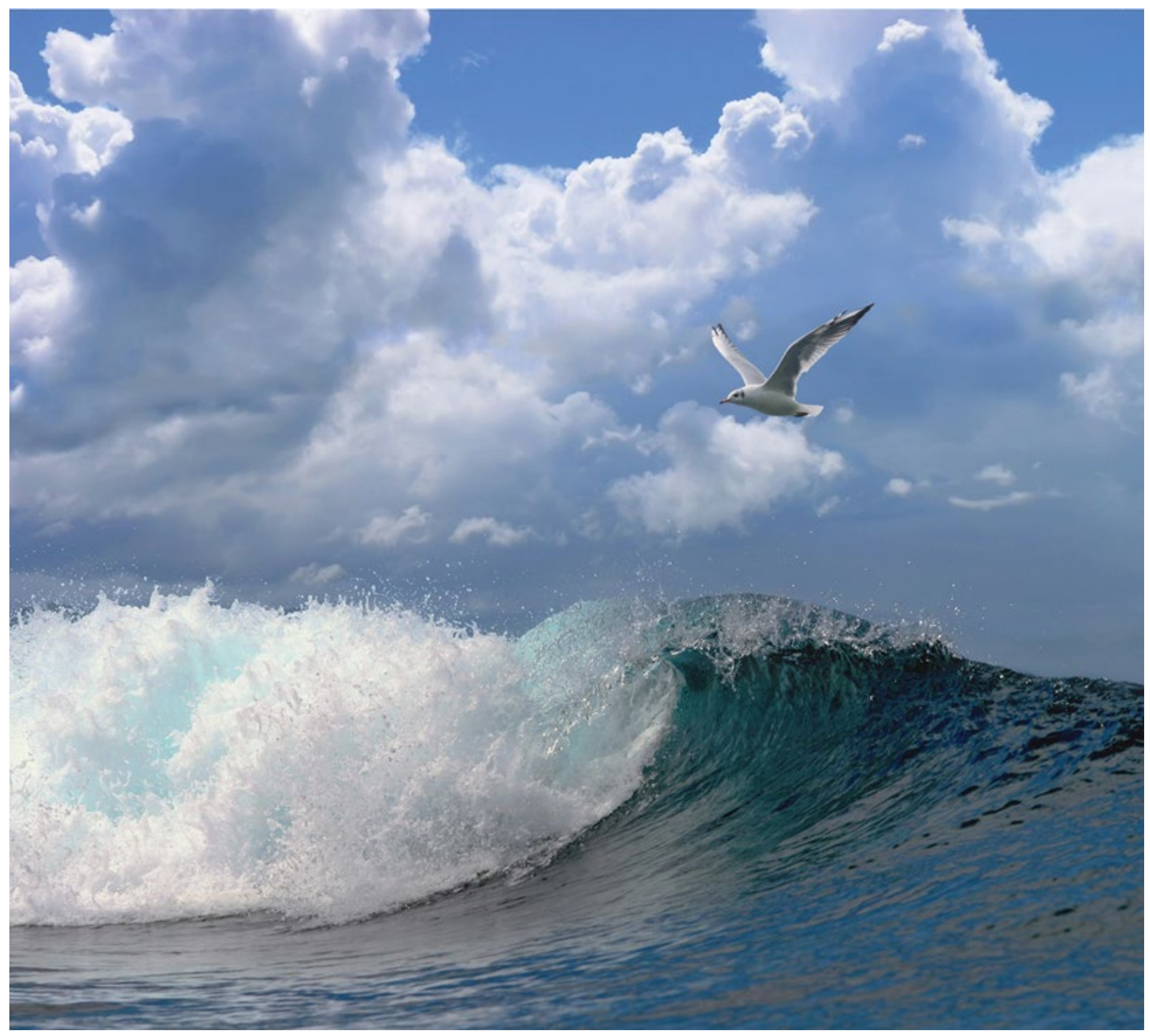

\title{
Sources of European flat oysters (Ostrea edulis L.) for restoration projects in the Dutch North Sea
}




\section{Sources of European flat oysters (Ostrea edulis L.) for restoration projects in the Dutch North Sea}

Author(s): $\quad$ Pauline Kamermans, Ainhoa Blanco and Pim van Dalen

Publication date: October 2020

This research project was carried out by Wageningen Marine Research at the request of and with funding from the Ministry of Agriculture, Nature and Food Quality for the purposes of Policy Support Research Theme 'Nature inclusive Energy' (project no. BO-43-023.03-003).

Wageningen Marine Research

Yerseke, October 2020

Wageningen Marine Research report C085/20 
Keywords: Ostrea edulis, flat oyster, restoration.

Client: Ministry of Agriculture, Nature and Food Quality, Department of Nature and Biodiversity Attn: Mr E. Knegtering

PO Box 20401

2500 EK The Hague

BAS code BO-43-023.03-003

Ministry of Agriculture, Nature and Food Quality, Department of Nature and Biodiversity Attn: Mr E. Knegtering

This report can be downloaded for free from https://doi.org/10.18174/532003

Wageningen Marine Research provides no printed copies of reports

Wageningen Marine Research is ISO 9001:2015 certified.

(c) Wageningen Marine Research

\begin{tabular}{|c|c|}
\hline $\begin{array}{l}\text { Wageningen Marine Research, an institute } \\
\text { within the legal entity Stichting }\end{array}$ & for damage resulting from applications of the results of work or other data \\
\hline Wageningen Research (a foundation under & obtained from Wageningen Marine Research. Client indemnifies Wageningen \\
\hline Dutch private law) represented by Dr. & Marine Research from claims of third parties in connection with this application. \\
\hline M.C.Th. Scholten, Managing Director & $\begin{array}{l}\text { All rights reserved. No part of this publication may be reproduced and / or } \\
\text { published, photocopied or used in any other way without the written permission }\end{array}$ \\
\hline
\end{tabular}

WMR BTW nr. NL 8113.83.696.B16.

Code BIC/SWIFT address: RABONL2U

IBAN code: NL 73 RABO 0373599285 


\section{Contents}

1.1 European flat oyster restoration in the Dutch North Sea 12

1.2 Ostrea edulis biology $\quad 13$

1.2.1 Anatomy 13

1.2.2 Life cycle 14

1.2.3 Distribution and genetic characterisation 14

$\begin{array}{lll}\text { 1.2.4 Diseases and fouling organisms } & 17\end{array}$

$2 \quad$ Assignment $r$

$\begin{array}{llr}2.1 & \text { Research questions } & 18\end{array}$

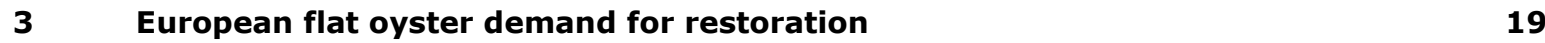

3.1 Type of oysters and quality requirements $\quad 19$

$\begin{array}{lll}3.2 & \text { Desired amount of oysters } & 20\end{array}$

$\begin{array}{lll}3.3 & \text { Current initiatives in Atlantic Europe } & 21\end{array}$

3.3.1 the Netherlands $\quad 21$

$\begin{array}{lll}3.3 .2 & \text { Europe } & 22\end{array}$

3.3.3 Native Oyster Restoration Alliance (NORA) 24

$\begin{array}{llr}4 & \text { European flat oyster supply } & 27\end{array}$

$\begin{array}{llr}4.1 & \text { Production methods } & 27\end{array}$

$\begin{array}{lll}4.1 .1 & \text { Hatchery and nursery } & 27\end{array}$

$\begin{array}{ll}\text { 4.1.2 Ponds for spat and adults } & 29\end{array}$

4.1.3 Spat collectors and culture in the field 30

4.1.4 Harvest from wild beds $\quad 32$

$\begin{array}{lll}4.2 & \text { Producers } & 32\end{array}$

$5 \quad$ Conclusions and recommendations $\quad 38$

$\begin{array}{lll}5.1 & \text { Options to reach the demand of starting material } & 38\end{array}$

$\begin{array}{lll}5.1 .1 & \text { Adult oysters } & 40\end{array}$

$\begin{array}{lll}\text { 5.1.2 Spat from field and ponds } & 41\end{array}$

$\begin{array}{lll}5.1 .3 & \text { Hatchery spat } & 41\end{array}$

$\begin{array}{lll}5.2 & \text { Recommendations } & 44\end{array}$

$\begin{array}{llr}6 & \text { Acknowledgements } & 46\end{array}$

$\begin{array}{llr}7 & \text { Quality Assurance } & 47\end{array}$

$\begin{array}{lr}\text { References } & 48\end{array}$

$\begin{array}{lr}\text { Justification } & 54\end{array}$ 


\section{Samenvatting}

Dit rapport beschrijft de biologie van de platte oester en geeft een overzicht van de behoefte aan platte oesters voor natuurherstelprojecten. Het geeft een samenvatting van de huidige initiatieven in Nederland en Europa en beschrijft de verschillende productiemethoden met hun voor- en nadelen, platte-oester-producenten en opties om aan de vraag van natuurherstelprojecten te voldoen.

De platte oester (Ostrea edulis) was een algemeen voorkomende soort in de Noordzee, Zuiderzee en Zeeuwse estuaria tot het einde van de $19^{\text {de }}$ eeuw. Daarna werd de visserij te intensief en verminderde de populatie in de Noordzee snel tot sporadische exemplaren aan het begin van de $20^{\text {ste }}$ eeuw. Verschillende factoren motiveren actief herstel van de platte oester. Platteoesterbanken zijn een bedreigde soort en habitat waarvoor beschermingsmaatregelen worden aanbevolen (OSPAR 2008, 2013). Oesterbanken vormden een sleutelelement in de Noordzee door hard substraat te bieden in een zachtsubstraatomgeving. Dit is belangrijk voor biodiversiteit, koppeling van benthische en pelagische ecosystemen, regulering van waterkwaliteit en verhoging van visproductie. Omdat platte oesters niet langer in grote hoeveelheden voorkomen in de Noordzee zijn herstelprojecten afhankelijk van aanvoer van oesters van elders.

Platte oesters planten zich voort door in de zomer larven te produceren. De oesters kunnen gedurende hun leven wisselen van geslacht (sexe). In tegenstelling tot de meeste andere schelpdiersoorten waarbij bevruchting in de waterkolom plaats vindt, vindt bevruchting van de eieren van vrouwtjes door het sperma van de mannetjes plaats in de mantelholte van het vrouwtje. Daar ontwikkelen de larven zich de eerste 10 dagen (broedzorg). Vervolgens zwemmen ze nog ongeveer 10 dagen rond alvorens zich permanent te vestigen op een harde ondergrond (substraat). Dan worden ze broed genoemd. Dit broed groeit vervolgens in ongeveer 2-3 jaar uit tot volwassen oester. Platte oesters komen voor van Noorwegen tot Marokko en van de Middellandse tot de Zwarte Zee. Genetische differentiatie tussen platte oesterpopulaties zijn klein. Dit is waarschijnlijk een gevolg van de vele oestertransporten die in het verleden hebben plaatsgevonden. Meer geavanceerde technieken laten wel geografische verschillen in genetische samenstelling zien.

Er zijn twee belangrijke parasitaire ziekteverwekkers voor O. edulis: Marteilia refringens en Bonamia ostrea. Bonamia komt voor in de Grevelingen en de Oosterschelde in Nederland, en in oestergebieden in Frankrijk, Ierland, het Verenigd Koninkrijk en Spanje, maar sommige baaien zijn ziektevrij. Marteilia komt voor langs de Atlantische kust van Frankrijk, Spanje en Portugal, in de Middellandse Zee en in de Adriatische Zee. Met behulp van fokprogramma's kunnen significante voordelen voor ziekteresistentie worden behaald. Maar door de gecompliceerde levenscyclus met broedzorg zijn er nog geen grootschalige fokprogramma's opgezet. In het buitenwater voorkomende oesters kunnen andere organismen bevatten, die ofwel op de schelp groeien, of die in de mantelholte aanwezig zijn. Bij verplaatsing van de oesters kan dit risico's veroorzaken voor introductie van niet-inheemse soorten, waaronder ziekteverwekkers, zoals protisten, bacteriën en virussen.

Platte oesters zijn beschikbaar als volwassenen of als broed. Deze zijn ofwel opgevist van natuurlijke banken of kweekpercelen, ofwel geproduceerd met behulp van collectoren in het veld, in speciaal daarvoor aangelegde vijvers, of in broedhuizen. De kwaliteitseisen voor platte oesters voor natuurherstelprojecten zijn:

- $\quad$ vrij van ziekteverwekkers

- $\quad$ indien mogelijk tolerantie of resistentie tegen ziektes

- $\quad$ geen aanwezigheid van niet-inheemse soorten

- $\quad$ goede overleving, groei en reproductie

- $\quad$ aangepast aan de lokale omgeving

- $\quad$ hoogst mogelijke genetische diversiteit (geldt ook voor gekweekte oesters)

- kostenefficiënt. 
Het doel van natuurherstelprojecten is het aanleggen van zichzelf in stand houdende banken. De kritische massa die daarvoor nodig is wordt gedefinieerd als het aantal platte oesters dat voldoende larven kan produceren die voor succesvolle vestiging en overleving van broed van een bank zorgen. Inschattingen van het aantal lopen uiteen, maar een minimum van 20.000 oesters lijkt aannemelijk.

Platte-oesterherstel in Nederland begon in 2014 met een aantal haalbaarheidsstudies gefinancierd door de overheid. In 2016 startte de eerste pilot in de Voordelta geïnitieerd door ARK Natuurontwikkeling en het Wereld Natuur Fonds en uiteindelijk gefinancierd door diverse partijen. Verder offshore zijn drie nieuwe pilots gestart in 2018 (Borkumse Stenen gefinancierd door het Wereld Natuur Fonds en ARK Natuurontwikkeling; windpark Gemini gefinancierd door Gemini, Edmelja B.V. en het Wereld Natuur Fonds; windpark Luchterduinen initieel medegefinancierd als LIFE-IP-project en vervolgens door Eneco, Van Oord, ASN Bank, Stichting de Noordzee en Natuur en Milieu). Daarnaast is Van Oord twee pilots aan het voorbereiden in het windpark Borssele in het kader van een natuurinclusiefbouwenverplichting. Andere platte-oesterherstelprojecten vinden plaats in Engeland, Wales, Schotland, Frankrijk en Duitsland. Als uitgangsmateriaal wordt gebruik gemaakt van zowel getransplanteerde volwassen oesters (Nederland, Schotland) als geproduceerd broed (Duitsland). Verder worden moederoesters uitgezet (Nederland, Engeland) en wordt vestigingssubstraat aangeboden (Nederland, Engeland, Schotland, Frankrijk). 
De voor- en nadelen van de verschillende methoden waarop platte oesters verkregen kunnen worden zijn samengevat in onderstaande tabel.

\begin{tabular}{|c|c|c|c|}
\hline Optie & Voordeel & Nadeel / risico & Maatregelen \\
\hline \multirow{5}{*}{$\begin{array}{l}\text { Verzamelen } \\
\text { van } \\
\text { volwassen } \\
\text { oesters }\end{array}$} & $\begin{array}{l}\text { Mogelijkheid tot } \\
\text { larvenproductie vanaf } \\
\text { eerste jaar van } \\
\text { herstel pilot }\end{array}$ & $\begin{array}{l}\text { Mannetjes en vrouwtjes } \\
\text { nodig voor voortplanting }\end{array}$ & $\begin{array}{l}\text { Beginpopulatie moet } \\
\text { verschillende groottes } \\
\text { bevatten om aanwezigheid } \\
\text { van mannetjes en } \\
\text { vrouwtjes te verzekeren }\end{array}$ \\
\hline & $\begin{array}{l}\text { Hoge genetische } \\
\text { diversiteit }\end{array}$ & Geen risico & \\
\hline & & $\begin{array}{l}\text { Mogelijkheid tot } \\
\text { aanwezigheid van } \\
\text { uitheemse soorten } \\
\text { gevestigd op schelpen of in } \\
\text { mantelholte }\end{array}$ & $\begin{array}{l}\text { Behandeling voor } \\
\text { verwijderen van niet- } \\
\text { inheemse soorten nodig, is } \\
\text { beschikbaar, maar een } \\
\text { potentieel risico kan niet } \\
100 \% \text { worden uitgesloten }\end{array}$ \\
\hline & & $\begin{array}{l}\text { Grootte van bestaande } \\
\text { populatie wordt verminderd }\end{array}$ & $\begin{array}{l}\text { Management van natuurlijk } \\
\text { bed }\end{array}$ \\
\hline & & $\begin{array}{l}\text { Oesters kunnen } \\
\text { ziekteverwekkers bevatten }\end{array}$ & $\begin{array}{l}\text { Alleen oester toegestaan } \\
\text { uit ziekte-vrije gebieden }\end{array}$ \\
\hline \multirow{5}{*}{$\begin{array}{l}\text { Verzamelen } \\
\text { van broed in } \\
\text { het veld of } \\
\text { productie in } \\
\text { vijvers } \\
\text { (ponds) }\end{array}$} & $\begin{array}{l}\text { Geen vermindering } \\
\text { van grootte } \\
\text { bestaande populatie }\end{array}$ & Geen risico & \\
\hline & $\begin{array}{l}\text { Gematigde } \\
\text { genetische diversiteit }\end{array}$ & Gematigd risico op inteelt & $\begin{array}{l}\text { Gebruik broed van } \\
\text { verschillende locaties en } \\
\text { vijvers }\end{array}$ \\
\hline & & $\begin{array}{l}\text { Mogelijkheid tot } \\
\text { aanwezigheid van } \\
\text { uitheemse soorten } \\
\text { gevestigd op schelpen of in } \\
\text { mantelholte }\end{array}$ & $\begin{array}{l}\text { Behandeling voor } \\
\text { verwijderen van niet- } \\
\text { inheemse soorten nodig, is } \\
\text { nog niet beschikbaar }\end{array}$ \\
\hline & & $\begin{array}{l}\text { Vestiging van broed } 1 \times \text { per } \\
\text { jaar en onregelmatig } \\
\text { tussen jaren }\end{array}$ & $\begin{array}{l}\text { Gebruik broed van } \\
\text { verschillende locaties en } \\
\text { vijvers }\end{array}$ \\
\hline & & $\begin{array}{l}\text { Oesters kunnen } \\
\text { ziekteverwekkers bevatten }\end{array}$ & $\begin{array}{l}\text { Alleen oester toegestaan } \\
\text { uit ziekte-vrije gebieden en } \\
\text { vijvers }\end{array}$ \\
\hline \multirow{5}{*}{$\begin{array}{l}\text { Productie } \\
\text { van broed in } \\
\text { broedhuis } \\
\text { (hatchery) }\end{array}$} & $\begin{array}{l}\text { Geen vermindering } \\
\text { van grootte } \\
\text { bestaande populatie }\end{array}$ & Geen risico & \\
\hline & $\begin{array}{l}\text { Geen behandeling } \\
\text { voor verwijderen van } \\
\text { niet inheemse } \\
\text { soorten nodig } \\
\end{array}$ & Geen risico & \\
\hline & $\begin{array}{l}\text { Mogelijkheid tot } \\
\text { ziekte- } \\
\text { resistent/tolerant } \\
\text { kweken }\end{array}$ & $\begin{array}{l}\text { Methode is in ontwikkeling } \\
\text { (zie } 5.1 .3 \text { ) en eerste } \\
\text { resultaten zijn } \\
\text { veelbelovend }\end{array}$ & Ontwikkeling voortzetten \\
\hline & & $\begin{array}{l}\text { Aanbod is gelimiteerd, } \\
\text { mede door technische } \\
\text { belemmeringen in } \\
\text { productie }\end{array}$ & $\begin{array}{l}\text { Onderzoek uitvoeren om } \\
\text { belemmeringen op te } \\
\text { lossen }\end{array}$ \\
\hline & $\begin{array}{l}\text { Lage genetische } \\
\text { diversiteit }\end{array}$ & Risico op inteelt & $\begin{array}{l}\text { Gebruik broed van } \\
\text { verschillende broedstocks }\end{array}$ \\
\hline
\end{tabular}


Met de juiste voorzorgsmaatregelen zijn oesters vrij van ziekteverwekkers en zonder aanwezigheid van niet-inheemse soorten en met voldoende genetische diversiteit beschikbaar. Productie van broed in een broedhuis geeft het minste risico voor de omgeving. Voor herstelprojecten wordt het produceren van broed op schelpen aangeraden. Er zijn 11 broedhuizen in Europa die ziektevrije platte oesters kunnen produceren. Broedhuizen produceren voor verdere opkweek tot consumptieformaat. Hierbij is het eindproduct van het broedhuis individuele broedjes en niet meerdere broedjes op een schelp. De meeste broedhuizen zijn momenteel niet toegespitst op platte-oesterproductie voor natuurherstel. Een optie om aan de vraag te voldoen is het opzetten van een broedhuis voor platte oester broed speciaal voor restoratieprojecten. Globale kosten zijn $€ 580.000$ investeringskosten en $€ 530.000$ per jaar operationele kosten voor een broedhuis dat 10 miljoen uit te zetten broed per jaar produceert. Hierbij is het uitgangspunt dat broed op schelpen wordt geproduceerd die kort na vestiging kunnen worden uitgezet in de oesterherstelpilots. Bij productie in een broedhuis is de genetische diversiteit een aandachtspunt. Door gebruik te maken van broed uit verschillende broedhuizen kan de genetische diversiteit worden vergroot. $\mathrm{Er}$ is nog weinig ervaring met het uitzetten van platte-oesterbroed op schelpen ('spat on shell'). Daarom wordt onderzoek aangeraden naar de meest effectieve grootte van het broed voor uitzetten en de meest effectieve periode in het jaar. Daarnaast is een onderzoeksprogramma aan te raden dat de huidige belemmeringen bij productie in een broedhuis aanpakt. Dit kan zich richten op verbeteren van overleving van larven, vergroten van overleving bij vestiging, verhogen van genetische diversiteit en verkrijgen van ziekteresistentie. 


\section{Summary}

This report describes the biology of the flat oyster and gives an overview of the demand for flat oysters for nature restoration projects. It gives a summary of the current initiatives in the Netherlands and Europe and describes the different production methods with their advantages and disadvantages, flat oyster producers and options to reach the demand of nature restoration projects.

Until about a century ago, European flat oyster (Ostrea edulis) beds constituted an important habitat in the North Sea. However, by the end of the 19th century the flat oyster fishery became too intensive, which caused the oyster population to decline rapidly. By the beginning of the 20th century, the oyster beds were already decimated. Several factors motivate flat oyster restoration in the North Sea. Flat oyster beds are a threatened species and habitat (OSPAR Commission 2008) for which protection and conservation measures have been recommended (OSPAR Commission 2013). Flat oyster beds once constituted a key element of a rich North Sea. Oyster beds are some of the most striking structures in soft-sediment environments, providing many ecosystem services, including the provision of habitat, which is important for biodiversity, pelagic-benthic ecosystem coupling, shoreline stabilization, water quality regulation, and the enhancement of fishery production. Flat oysters do not occur in large quantities in the North Sea. Thus, restoration projects depend on supply from elsewhere.

Flat oysters produce larvae in summer. Mature flat oysters can switch between sexes to be male or female. Unlike most other bivalve shellfish species, where fertilisation takes place in the waterr column, eggs are fertilised in the mantle cavity of the female. Eggs remain in the mantle cavity of the female and develop into larvae with two shells in a period of one to two weeks. Then the larvae are released and spend around 10 days in the water column before settlement on hard substrate takes place. Then they are called spat. Spat grows to reproducing adults in about 2-3 years. Flat oysters ocur from Norway to Marocco and from the Mediterranean to the Black Sea. Genetic differentiation between flat oyster populations is small. This is probably a result of the many oyster transports that have taken place in history. More advanced techniques show geographic differences in genetic composition.

There are two main pathogens for O. edulis: Marteilia refringens and Bonamia ostrea. Bonamia, occurs in the Netherlands, France, Ireland, United Kingdom and Spain, but some bays are pathogen free. Marteilia occurs in flat oysters along the Atlantic coasts of France, Spain and Portugal and in the Mediterranean and Adriatic Sea. Significant gains for disease resistance could be obtained using selective breeding programs. Due to their complicated life cycle, no large-scale selective breeding programmes have yet been started for $O$. edulis. Oysters in the field can contain other organisms, either on their shell, or in the mantle cavity. Transfer of the oysters can include risks of introducing non-native species, among which pathogens, such as protists, bacteria and viruses.

Flat oysters are available as adults or as spat. These are either fished from natural beds or culture plots, or produced with collectors in the field, in spatting ponds, or in hatcheries. The quality requirements for flat oysters to be used in restoration pilots are:

- disease free

- $\quad$ tolerance or resistance against diseases when possible

- $\quad$ absence of non-native species

- good survival, growth and reproduction

- $\quad$ adapted to the local environment

- $\quad$ highest possible genetic diversity

- cost efficient.

The goal of nature restoration projects is to develop a self-sustaining bed. The critical mass needed to reach that is defined as the number of flat oysters that can produce sufficient larvae that will settle successfully and survive. Estimations vary, but a minimum of 20.000 oysters seems plausible. 
Flat oyster restoration and nature enhancement in the Dutch North Sea area started in 2014 with a number of feasibility studies funded by the government. In 2016, the first oyster pilot started in the Voordelta, a nearshore area in the North Sea. The pilot was initiated by ARK Natuurontwikkeling (ARK foundation for Nature Development) and the World Wide Fund for Nature (WWF) and the total project was funded by several parties. Further off shore three new pilots started in 2018 (Borkum Reef Ground financed by WWF and ARK Nature; wind farm Gemini financed by Gemini, Edmelja B.V and WWF; wind farm Luchterduinen initially financed as LIFE-IP project and after that by Enoco, Van Oord, ASN Bank, North Sea Foundation and Nature en Milieu). In addition, Van Oord has two pilots in wind farm Borssele as part of the requirement of nature inclusive building. Other flat oyster restoration projects take place in England, Wales, Scotland, France and Germany. Starting material is transplanted oysters (Netherlands and Scotland) or spat from a hatchery (Germany). Furthermore, broodstock oysters are deployed (England, Netherlands) and settlement substrate is offered (Netherlands, England, Scotland, France). 
The advantages and disadvantages of the different methods to obtain flat oysters are summarized in the table below.

\begin{tabular}{|c|c|c|c|}
\hline Option & Advantage & Disadvantage / risk & Contingency plan \\
\hline \multirow{5}{*}{$\begin{array}{l}\text { Collection of } \\
\text { adults }\end{array}$} & $\begin{array}{l}\text { Possibility of larval } \\
\text { production starting } \\
\text { from the first year of } \\
\text { restoration project }\end{array}$ & $\begin{array}{l}\text { Need males and females } \\
\text { for reproduction }\end{array}$ & $\begin{array}{l}\text { Starting population must } \\
\text { contain different sizes to } \\
\text { ensure presence of both } \\
\text { sexes. }\end{array}$ \\
\hline & High genetic diversity & No risk & \\
\hline & & $\begin{array}{l}\text { Possibility of alien species } \\
\text { attached to the shells and } \\
\text { inside mantle cavity }\end{array}$ & $\begin{array}{l}\text { Treatment needed to } \\
\text { remove alien species } \\
\text { attached to the shells and } \\
\text { inside mantle cavity. This } \\
\text { is available, but a potential } \\
\text { risk cannot be } 100 \% \\
\text { eliminated. }\end{array}$ \\
\hline & & $\begin{array}{l}\text { Size of source population is } \\
\text { reduced }\end{array}$ & Management of natural bed \\
\hline & & $\begin{array}{l}\text { Oysters may carry } \\
\text { pathogens }\end{array}$ & $\begin{array}{l}\text { Only oysters allowed from } \\
\text { disease-free areas }\end{array}$ \\
\hline \multirow{5}{*}{$\begin{array}{l}\text { Spat } \\
\text { collection in } \\
\text { ponds or in } \\
\text { field }\end{array}$} & $\begin{array}{l}\text { No reduction of } \\
\text { source population }\end{array}$ & No risk & \\
\hline & $\begin{array}{l}\text { Moderate genetic } \\
\text { diversity }\end{array}$ & Moderate risk of inbreeding & $\begin{array}{l}\text { Use spat from different } \\
\text { locations and spatting } \\
\text { ponds }\end{array}$ \\
\hline & & $\begin{array}{l}\text { Possibility of alien species } \\
\text { attached to the shells and } \\
\text { inside mantle cavity }\end{array}$ & $\begin{array}{l}\text { Treatment needed to } \\
\text { potentially remove alien } \\
\text { species, is not available yet }\end{array}$ \\
\hline & & $\begin{array}{l}\text { Settlement only once a } \\
\text { year and irregular between } \\
\text { years }\end{array}$ & $\begin{array}{l}\text { Use spat from different } \\
\text { locations and spatting } \\
\text { ponds }\end{array}$ \\
\hline & & $\begin{array}{l}\text { Oysters may carry } \\
\text { pathogens }\end{array}$ & $\begin{array}{l}\text { Only oysters allowed from } \\
\text { disease-free areas and } \\
\text { ponds }\end{array}$ \\
\hline \multirow{5}{*}{$\begin{array}{l}\text { Hatchery } \\
\text { production }\end{array}$} & $\begin{array}{l}\text { No reduction of } \\
\text { source population }\end{array}$ & No risk & \\
\hline & No treatment needed & No risk & \\
\hline & $\begin{array}{l}\text { Production of disease } \\
\text { resistant/tolerant } \\
\text { oysters }\end{array}$ & $\begin{array}{l}\text { Method is under } \\
\text { development (see 5.1.3) } \\
\text { and first results are } \\
\text { promising }\end{array}$ & Continue development \\
\hline & & $\begin{array}{l}\text { Supply is limited, in part } \\
\text { due to current technical } \\
\text { bottle necks in production }\end{array}$ & $\begin{array}{l}\text { Carry out research on } \\
\text { solving the bottle necks }\end{array}$ \\
\hline & Low genetic diversity & Risk of inbreeding & $\begin{array}{l}\text { Use spat from different } \\
\text { broodstocks }\end{array}$ \\
\hline
\end{tabular}

With the right precautions oysters are available that are disease free without non-native species and with sufficient genetic diversity. Production of spat in hatcheries has the lowest risk for the environment. Hatchery production is advised for restoration projects. There are 11 hatcheries in Europe that can provide disease-free flat oysters. Hatcheries produce for on-growing for the consumer. The end product of the hatchery is therefore single spat and not multiple spat on a shell. Most hatcheries are not focusing on production of spat on shell for restoration projects. An option to reach the demand is to start a hatchery for restoration projects. A rough estimate of the costs is 
$€ 580.000$ investments and $€ 530.000$ operational cost for a hatchery that will produce 10 million spat per year. The starting point is that spat on shell is produced that can be deployed shortly after settlement. Genetic diversity is an issue in hatchery production. This can be enhanced by using spat from different hatcheries. Experience with deployment of spat on shell of flat oysters is limited. Thus, research is recommended to establish the most effective size of the spat and the most effective period of the year. In addition, a research programme is recommended to tackle the current bottle necks in flat oyster hatchery production. This can focus on enhanced survival of larvae and during metamorphosis to spat, improving genetic diversity and reducing disease susceptibility. 


\subsection{European flat oyster restoration in the Dutch North Sea}

Until about a century ago, European flat oyster (Ostrea edulis) beds constituted an important habitat in the North Sea. The flat oyster was a key species that once existed in the North Sea ecosystem, a fact that has almost disappeared from public memory. According to field surveys conducted in the $19^{\text {th }}$ and early $20^{\text {th }}$ century, the North Sea harboured substantial areas of oyster beds in that time (over 25,000 km², Olsen, 1883; Fischereikarte 1915 in Gercken \& Schmidt, 2014; Houziaux, 2008). However, by the end of the 19th century the flat oyster fishery became too intensive, which caused the oyster population to decline rapidly (Gercken \& Schmidt, 2014; Houziaux, 2008). By the beginning of the 20th century, the oyster beds were already decimated (Fischereikarte 1915 in Gercken \& Schmidt, 2014). Later, other types of bottom trawling fisheries also impacted on the remaining beds. Other reasons for the decimation are not documented. As a result, the oyster community, including related species, disappeared from the North Sea (Gercken \& Schmidt, 2014; Houziaux, 2008).

Several factors motivate flat oyster restoration in the North Sea. Flat oyster beds are a threatened species and habitat (OSPAR Commission 2008) for which protection and conservation measures have been recommended (OSPAR Commission 2013). Under the EU Habitats Directive, Habitat type 'reefs' (H1170) may include - for the North Atlantic, including the North Sea - reef-forming animals including species of polychaetes, bivalves and cold water corals (European Commission 2013). Under the EU Marine Strategy Framework Directive, the Netherlands have formulated the following as one of the socalled environmental targets for 'benthic habitats': return and recovery of biogenic reefs including flat oyster beds (D6T5) (Min. IenW \& Min. LNV 2018). Flat oyster beds once constituted a key element of a rich North Sea. Oyster beds are some of the most striking structures in soft-sediment environments, providing many ecosystem services, including the provision of habitat, which is important for biodiversity (Bruno et al., 2003; Bouma et al., 2009), pelagic-benthic ecosystem coupling, shoreline stabilization, water quality regulation, and the enhancement of fishery production (Lenihan \& Peterson, 1998; Zu Ermgassen et al., 2016b). There is a lack of knowledge on the ecosystem services provided by deep-water flat oyster beds, as most studies have focused on the intertidal reefs of the Eastern oysters (Crassostrea virginica) and Pacific oyster (Crassostrea gigas, also called Magellana gigas). Despite this, some mechanisms are assumed to be generic for species and environments. Zwerschke et al. (2016), for example, demonstrated that the species facilitations function of the intertidal native European oyster bed is similar to the invasive Pacific oyster reefs. Beds of the European oyster Ostrea edulis can function as a habitat for many species. Oyster beds provide settlement substrate for epibenthic flora and fauna, food and shelter to mobile invertebrates (e.g., crab, lobster, and shrimps), and fish can use the beds as shelter (particularly in the juvenile stage) and spawning grounds (e.g., herring) (e.g. zu Ermgassen et al., 2016b). The hard substrate, formed by the 0 . edulis shells, increases in time through recruitment and growth, harboring higher species diversity than non-living hard substrate (Smyth \& Roberts, 2010; Christianen et al., 2018).

Reefs formed by oysters, as ecosystem engineers, impact the benthic environment by altering the biogeochemical and physical properties of the sediment, affecting community composition, abundance, and species richness. As filter feeders, oysters enhance the pelagic-benthic ecosystem coupling through the production of fecal and pseudofecal deposits, followed by mineralization (Newell, 2004; Kellogg et al., 2013), which may stimulate phytoplankton turnover, enhancing primary production (Dame \& Prins, 1997). In addition, reefs of filter feeders can concentrate and trap organic matter, which fuel local benthic food webs. Concentration of organic matter has been demonstrated for intertidal mixed blue mussel (Mytilus edulis) and Pacific oyster reefs (Van der Zee et al., 2012), deep reef structures of the cold-water coral Desmophyllum pertusum (van Oevelen et al., 2009), and tubeworm Lanice conchilega reefs (de Smet et al., 2016). De Smet et al. (2016) demonstrated that $L$. conchilega can significantly concentrate and trap organic matter, produced in an area no less than 15 
times the reef area, within their reef food web, resulting in a higher macrofaunal biomass and a more diverse food web than in the absence of the reef.

Large beds of bivalves can also have a major effect on the local fine sediment dynamics (Van der Heide et al., 2014; Ysebaert et al., 2009). The large expanses of oyster beds in the 19th century must have had a large-scale effect on turbidity in the North Sea. The area of the old "oyster grounds" is characterized by relatively fine sediment (Puls and Sündermann, 1990), which, under high wave conditions, can resuspend into the water column affecting light penetration. It is to be expected that the presence of $25,000 \mathrm{~km}^{2}$ of oyster bed has affected these processes significantly. To what extent the changes in light penetration may have also affected local primary production is unknown. Habitat formed by the oysters, combined with biodeposition, increases prey abundance, which is the driving force for enhanced fish production. Zu Ermgassen et al. (2016b) quantitatively estimated enhanced fish and mobile invertebrate production by oyster reefs. In the Gulf of Mexico, gross production was increased with $397 \mathrm{~g} \mathrm{~m}^{-2} \mathrm{y}^{-1}$ in the presence of oyster reefs (zu Ermgassen et al., 2016b). Korringa (1954) reported 208 species living in association with or on oyster beds in the Dutch Oosterschelde. Hence, restoration would provide opportunities for ecosystem services, such as the commercial exploitation of fish and mobile invertebrates, as well as flat oysters themselves; provided that exploitation methods are developed that leave the flat oyster beds intact. As a consequence, the loss of oyster beds leads to a less productive and less diverse ecosystem and the loss of ecosystem services. In the Wadden Sea, the disappearance of the oyster beds resulted in a less diverse and productive mudflat ecosystem (Reise \& Beusekom 2008).

Some large-scale projects that showed successful oyster reef restoration were carried out with the Eastern oyster (Crassostrea virginica) in Chesapeake Bay (USA), and O. edulis in Strangford Lough (Northern Ireland), and Limfjord (Denmark) (Brumbaugh et al. 2000; Dolmer and Hoffmann 2004; Kennedy and Roberts 2006). Together, these restoration projects show that the return and restoration of native oyster beds is feasible but only when conducted at a large scale, with high investments, when following a critical assessment of location suitability (e.g., temperature, low bottom shear stress), under presence of a substantial source of larvae in close proximity, with high availability of suitable substrate, and when located in areas without bottom disturbance as recommended by Beck et al. (2011) and Smaal et al. (2015).

\subsection{Ostrea edulis biology}

\subsubsection{Anatomy}

Oysters, including European flat oysters, are bivalves, the two shells are also called valves (Figure 1). The animal inside has a muscle to close and open the two valves. It is also attached to the shell with mantle tissue. It has gills to take up oxygen and filter food from the water.
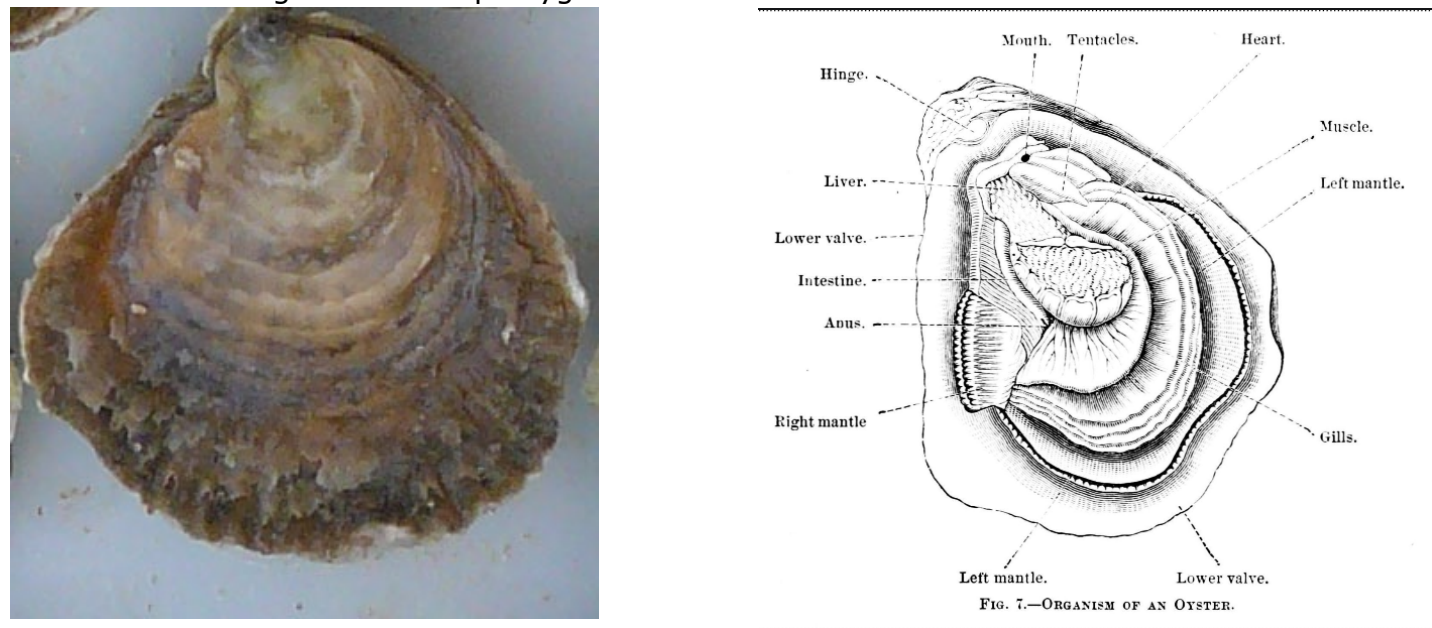

Figure 1. Ostrea edulis (picture Pauline Kamermans, drawing commons.wikimedia.org). 


\subsubsection{Life cycle}

Mature flat oysters can switch between sexes to be male or female (Walne 1974). Generally, flat oysters start as males and become females as they grow older. Older oysters can spawn twice during one season, once as a male and once as a female. Sperm cells, clustered in spermatozeugmata (O'Foighil 1989), are expelled through the exhalant siphon. Eggs remain in the mantle cavity of the female, where they are fertilized and develop into larvae with two shells in a period of one to two weeks (Figure 2). A recent analysis of a large dataset on larval abundance in the Oosterschelde and Lake Grevelingen in the Netherlands showed that the timing of maximal larval release can be predicted based on temperature (Maathuis et al., 2020). When the larvae are released, the shell length of the larvae is 170-190 $\mu \mathrm{m}$. During their free-swimming stage (another 8-17 days (Korringa 1956; Walne 1974)) the length increases to 290-360 $\mu \mathrm{m}$. Metamorphosis, from swimming larvae into sessile spat, depends on temperature and food availability for the larvae. Settlement, or spat fall, occurs when a suitable location is detected. A drop of cement is produced and the left valve is glued to the surface. As a result of the relative short free-swimming stage, compared to other bivalve species, the dispersal distance of $O$. edulis is limited (on average $1 \mathrm{~km}$ (Jackson, 2007)), although longer distances are occasionally possible during favourable conditions (up to more than $10 \mathrm{~km}$ based on a pelagic phase of 10-30 days (Muus and Dahlstrom, 1973)). Oyster spat settles on hard substrates, such as stones, shell fragments, or oyster shells. They adhere or fix themselves to the substrate and do not disperse further. Spat grows to reproducing adults in about 2-3 years (Walne 1974). They can live more than 20 years (FAO.org). For spat collection, calcified tiles have been employed in many areas and are still in use in Arcachon Bay (France) or tree branches are used in Mali Ston Bay (Croatia). Recent experiments carried out in the Voordelta showed that settlement is best on substrates that are deployed one to two weeks after the highest larval abundance (van den Brink et al., 2020). Oyster shells in existing oyster beds provide a settling substrate for oyster spat. Oyster bed development is therefore a self-reinforcing process, due to the positive feedback of existing oysters on successful recruitment and settlement (e.g., Eastern oyster, Jordan-Cooley et al., 2011). It implies that oyster beds have a critical mass below which recruitment may fail, due to limited substrate availability in relation to the number of larvae produced (Berghahn \& Ruth, 2005; Kennedy \& Roberts, 2006).

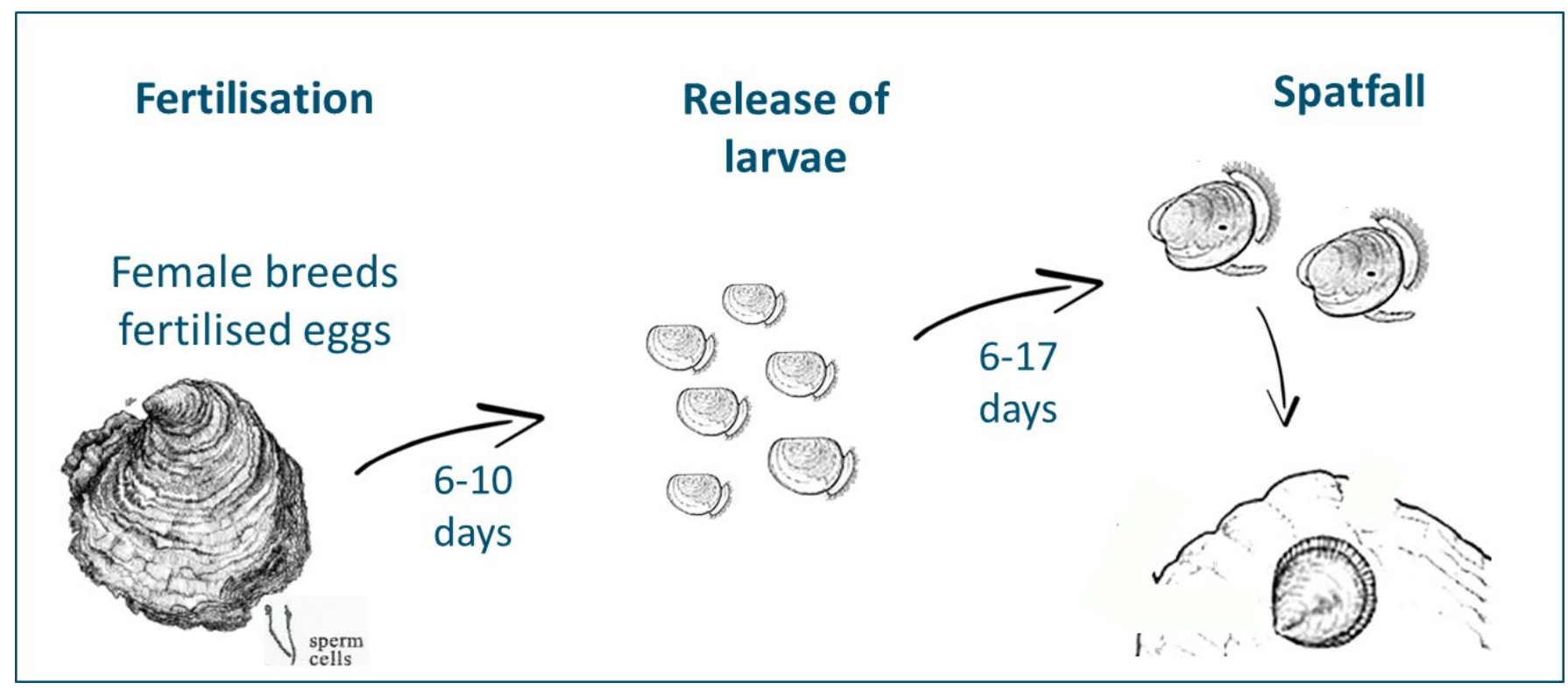

Figure 2. First phases of Ostrea edulis life cycle (adapted from Maathuis, 2018).

\subsubsection{Distribution and genetic characterisation}

Flat oysters occur from Norway to Morocco in the North-Eastern Atlantic, in the Mediterranean and in the Black Sea (Yonge, 1960). They live in intertidal areas (Montes et al., 1991) and down to a depth of $80 \mathrm{~m}$ (Hayward \& Ryland, 1998). Genetic differentiation exists between Atlantic, Mediterranean and 
Black Sea populations (Sobolewska \& Beaumont, 2005; Launey et al., 2002; Diaz-Almela et al., 2004). Ever since Roman times oysters have been translocated. Table 1 gives an overview of introduction of flat oysters into Dutch waters and export of Dutch flat oysters to other waters. From this table we can learn that the flat oysters populations are of mixed origin. This can explain the moderate genetic differentiation between Atlantic and Mediterranean $O$. edulis populations and a tendency for Atlantic populations to be less variable than Mediterranean ones (Launey et al., 2002). However, Vera et al. (2016) studied oyster populations in the Netherlands, Denmark, Ireland, England, France and Spain with more detailed methods and revealed three geographical genetic regions: (1) The Netherlands and Denmark; (2) France, Ireland and England; and (3) Spain. Guitierrez et al. (2017) showed high genetic similarity in 0 . edulis between Norway, Lake Grevelingen and Maine.

In addition, the data in table 1 show that diseases are transferred with the oysters. Furthermore, the data indicate that restocking was needed frequently, both in the Netherlands and with oysters from the Netherlands. The translocations were mainly for commercial purposes. Bromley et al. (2016) state that historically, the ability of oysters to breed after translocation was not considered important. However, it is important when the goal is to establish self-sustaining populations.

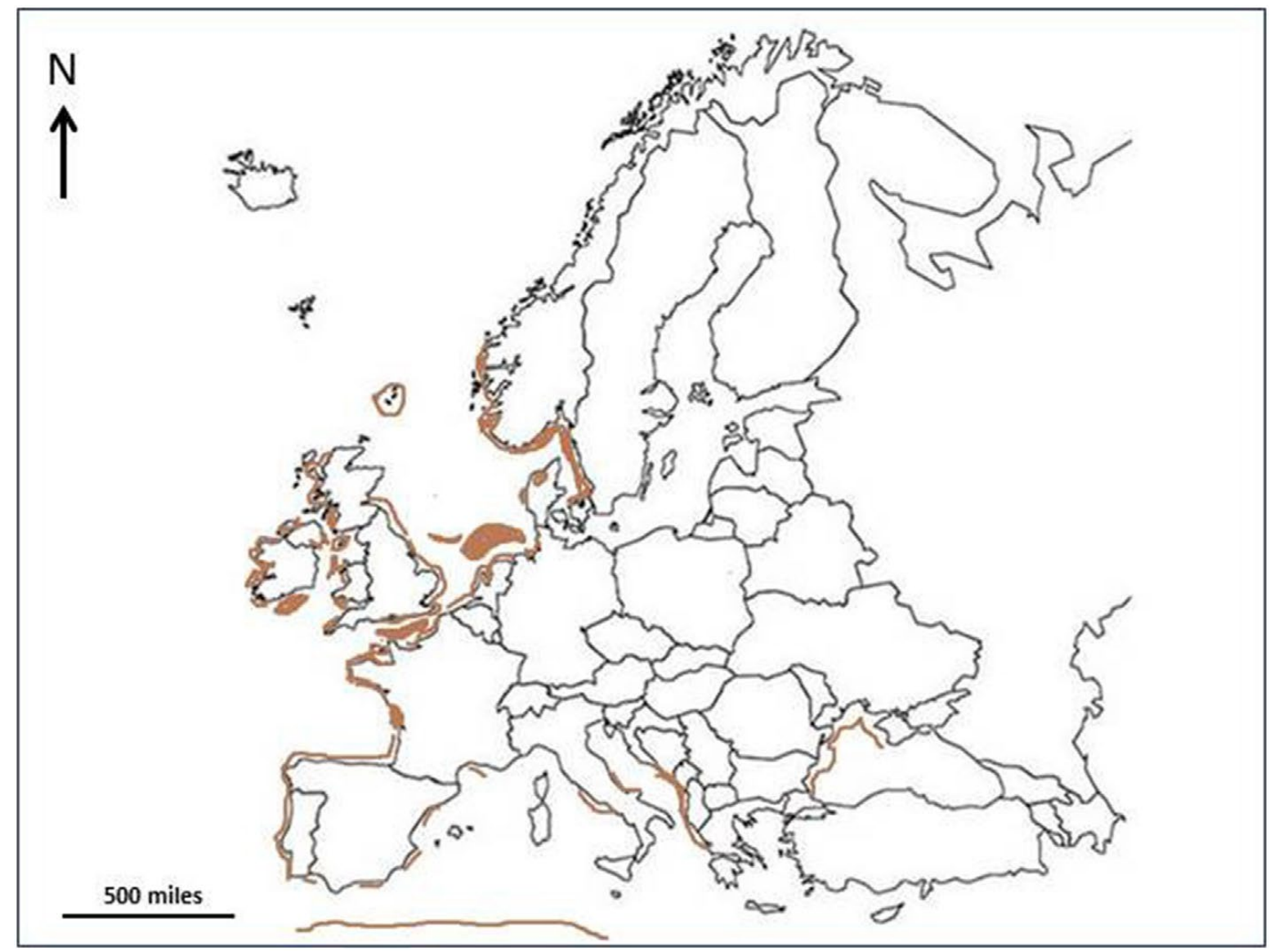

Figure 3. Historical natural distribution of Ostrea edulis (from Bromley et al., 2016). 
Table 1. Translocations of Ostrea edulis to and from the Netherlands. Based on Bromley et al (2016).

\begin{tabular}{|c|c|c|c|c|}
\hline From & To & Date & No. of oysters & Method/Purpose \\
\hline $\begin{array}{l}\text { Scotland: Firth of } \\
\text { Forth }\end{array}$ & the Netherlands & Before 1786 & Millions? & On growing, restocking \\
\hline SE England & the Netherlands & Before 1839 & Not stated & Fished by Dutch vessels \\
\hline Ireland & the Netherlands & $1860 \mathrm{~s}$ & Not stated & Restocking \\
\hline Ireland: Arklow & the Netherlands & 1868 & Not stated & Sale, restocking \\
\hline the Netherlands & England: Whitstable & Late 1800 s & Not stated & Restocking \\
\hline the Netherlands & Ireland: Sligo Bay & Ca. 1894 & 250,000 & Relaying on licenced beds \\
\hline $\begin{array}{l}\text { the Netherlands: } \\
\text { Oosterschelde }\end{array}$ & $\begin{array}{l}\text { Denmark: } \\
\text { Limfjorden }\end{array}$ & $\begin{array}{l}1922 \\
1923-1925 \\
1931\end{array}$ & $\begin{array}{l}200,000 \text { ( } 2 \text { yr old) } \\
2 \text { million per year } \\
18 \text { million }\end{array}$ & $\begin{array}{l}\text { Restocking } \\
\text { Restocking } \\
\text { Restocking }\end{array}$ \\
\hline $\begin{array}{l}\text { the Netherlands: } \\
\text { Oosterschelde }\end{array}$ & $\begin{array}{l}\text { France: Morbihan, } \\
\text { Brittany }\end{array}$ & $1922-1930$ & $\begin{array}{l}\text { Many millions over } \\
\text { several years }\end{array}$ & $\begin{array}{l}\text { Restocking after } 1921 / 22 \\
\text { mass mortality owing to } \\
\text { disease in France }\end{array}$ \\
\hline $\begin{array}{l}\text { the Netherlands: } \\
\text { Oosterschelde }\end{array}$ & USA: Maine & 1947-1949 & Ca. 9000 & $\begin{array}{l}\text { Feasibility study. Sent by } \\
\text { Korringa, led to hatchery and } \\
\text { natural population }\end{array}$ \\
\hline $\begin{array}{l}\text { France: Morbihan, } \\
\text { Brittany }\end{array}$ & the Netherlands & 1950s & Not stated & $\begin{array}{l}\text { Restocking after mass } \\
\text { mortality }\end{array}$ \\
\hline England: Whitstable & $\begin{array}{l}\text { the Netherlands: } \\
\text { Oosterschelde }\end{array}$ & 1900s up to 1977 & Not stated & $\begin{array}{l}\text { Fattening/on growing } \\
\text { /restocking }\end{array}$ \\
\hline the Netherlands & Wales & Early 1960s & Not stated & $\begin{array}{l}\text { Blamed for introduction of gill } \\
\text { disease and Dutch shell } \\
\text { disease to Wales }\end{array}$ \\
\hline France & $\begin{array}{l}\text { the Netherlands: } \\
\text { Wadden Sea }\end{array}$ & Pre 1962 & Large quantities & On growing /restocking \\
\hline France: Brittany & the Netherlands & $\begin{array}{l}\text { Early 1960s } \\
\text { Spring } 1967\end{array}$ & $\begin{array}{l}6 \text { million } \\
15 \text { million } \\
\end{array}$ & $\begin{array}{l}\text { Restocking after severe } \\
1962 / 63 \text { winter }\end{array}$ \\
\hline Adriatic & the Netherlands & Spring 1967 & Not stated & $\begin{array}{l}\text { Restocking after severe } \\
1962 / 63 \text { winter }\end{array}$ \\
\hline Ireland & Netherlands & Spring 1967 & Some & $\begin{array}{l}\text { Restocking after severe } \\
1962 / 63 \text { winter }\end{array}$ \\
\hline France & the Netherlands & Up to 19771980 & Not stated & $\begin{array}{l}\text { Restocking, blamed for } \\
\text { introduction of Bonamia to } \\
\text { Netherlands }\end{array}$ \\
\hline Greece & the Netherlands & Up to 1977 & Not stated & Restocking \\
\hline Italy & the Netherlands & Up to 1977 & Not stated & Restocking \\
\hline Norway & the Netherlands & Up to 1977 & $\begin{array}{l}1963 / 64>20 \text { million } \\
\text { juveniles }\end{array}$ & Restocking \\
\hline $\begin{array}{l}\text { Southern European } \\
\text { waters }\end{array}$ & the Netherlands & Not stated & Not stated & Restocking \\
\hline the Netherlands & $\begin{array}{l}\text { Canada: Prince } \\
\text { Edward Island }\end{array}$ & Not stated & Not stated & Not stated \\
\hline
\end{tabular}


There are two main pathogens for $O$. edulis: Marteilia refringens and Bonamia ostrea (Haenen et al., 2011). Both species are unicellular parasites and infection can cause death of the host. Bonamia, causing bonamiosis, occurs in the Netherlands, France, Ireland, United Kingdom and Spain, but some bays are pathogen free (Sas et al, 2020). Marteilia occurs in flat oysters along the Atlantic coasts of France, Spain and Portugal and in the Mediterranean and Adriatic Sea. The local Dutch O. edulis population in Lake Grevelingen is infected with Bonamia ostrea (Engelsma et al., 2010). There are no remaining flat oyster populations in the North Sea. Thus, it is unclear if the area is pathogen free. EU regulations, additional national policies and restoration guidelines aim to prevent the spread of notifiable pathogens like Bonamia and Marteilia as a result of oyster restoration efforts (OSPAR Commission 2013, under 3.1.h and NORA Recommendation, Pogoda et al. (2019), also see page 19). Therefore, oysters from Bonamia infected areas can only be used in the nearby Voordelta area, where Bonamia has been detected (Kamermans et al., 2018c). For all other areas of the Dutch North Sea, Bonamia-free oysters must be used. Recently, O. edulis was rediscovered in the Dutch Wadden Sea (van der Have et al., 2017). Off-spring of these oysters tested Bonamia free (pers. comm. P. Jacobs). In general, Bonamia-free oysters come from areas where the parasite has never been detected. These oysters are susceptible to the disease, as they have never been exposed to it. Oysters that come from areas where the parasite occurs may be tolerant (infected, but not affected by the parasite) or resistant (not infected even though exposed to the parasite). Ongoing efforts to supply oysters for Dutch restoration projects focus on local spat collection and hatchery production of disease free, and at the same time disease tolerant, spat (Kamermans et al., submitted).

Significant gains for disease resistance could be obtained using selective breeding programs. Producing spat with parents that have shown survival in Bonamia-infected areas results in offspring that is likely to also show better survival. B. ostreae was first observed in the Oosterschelde in 1980 and in Lake Grevelingen in 1988 (Van Banning 1982, 1991; Engelsma et al., 2010). This implies that the oysters present in these waters were exposed to the disease for a long period. Culloty et al. (2004) compared performance of oysters that had been selectively bred for resistance to $B$. ostreae (Rossmore, Cork harbour, Ireland), and oysters from two areas where Bonamia has been present for a long time (Lake Grevelingen, the Netherlands and Brittany, France) with oysters from four naïve populations where Bonamia had not been detected (Lough Foyle, Ireland; Tralee, Ireland; Lough Kishorn, Scotland; Mull, Scotland). Strains from these seven populations were translocated to Cork Harbour (Ireland), Lake Grevelingen (the Netherlands) and Brittany (France). The field trials indicated that Rossmore and Lake Grevelingen oysters showed lower mortality compared to other populations. Culloty et al. (2004) conclude that previous exposure in these populations has conferred some reduced susceptibility to the parasite compared to naive populations. In a follow up study spat was produced in the hatchery of Roem van Yerseke with broodstock from long-term exposed populations in Lake Grevelingen and the Oosterschelde and a naïve population in Limfjord in Denmark. Spat of all three groups was reared for 1 year in Lake Grevelingen. Survival was best in spat from Lake Grevelingen (OYSTERECOVER, 2013). It was concluded that Grevelingen should be considered as a candidate stock for starting a breeding programme in the Netherlands. Although this stock had the highest overall prevalence of infection, it also had the greatest growth and survival rate indicating that it may have formed some local tolerance to the disease. In addition, Vera et al. (submitted) identified genomic regions and markers associated with Bonamia resistance in European flat oyster. This tool can facilitate obtaining Bonamia-resistant stocks. A study in France with selected strains showed better resistance against Bonamia and better growth (Baud et al 1997, Naciri-Graven et al 1998, Naciri-Graven et al 1999). No large-scale selective breeding programmes have yet been started for $O$. edulis. Loss of genetic variability is a risk in hatchery production (Launey et al, 2001). Thus, determination of the number and genetic composition of breeders is important.

Oysters can contain other organisms either growing on the shells, or in the mantle cavity. Brenner et al (2014) reviewed risks associated with shellfish translocation, such as introduction of non-native species including pathogens like protists, bacteria and viruses. Many examples of severe ecological impacts have been documented worldwide owing to the intentional or unintentional translocation of animals (Brenner et al., 2014). It is therefore important to develop risk reduction methods which have not yet been documented to be incorporated into current fish health or environmental legislation (see treatment protocol on page 32). 


\section{Assignment}

This report gives an overview of European flat oyster demand by restoration projects. It summarises current initiatives in Europe and the Netherlands in particular. It describes production methods, supply by producers and short-term and long-term options to reach the demand. This includes risks for the environment considered from a nature protection point of view.

\section{$2.1 \quad$ Research questions}

a) What life stage of oysters can be used as starting material for restoration projects?

b) What are the quality requirements that can or need to be applied to these oysters?

c) What methods are available to produce or acquire oysters with the right quality and what are the advantages and disadvantages of these methods?

d) What are options to reach the demand of starting material for restoration projects (including setting up a hatchery)? 


\section{European flat oyster demand for restoration}

In this chapter the quality requirements and desired amounts of flat oysters that can be used as starting material for restoration projects are described. In addition, an overview of current initiatives in Europe is provided.

\subsection{Type of oysters and quality requirements}

In the past, the majority of oyster restoration efforts focused on recovering oyster fisheries (see Table 1). Nowadays, oysters are also restored for their ecosystem services. A lot of experience has been gained with restoration of intertidal oysters (Crassostrea virginica) at the East coast of the US (Baggett et al., 2014; zu Ermgassen et al., 2016a). There are two main strategies for restoration: adult transplants and juvenile seeding. Generally, restoration programmes are coupled with habitat restoration. In the US, oysters may still be present, hard substrate is often limiting. Therefore, large amounts of shell are introduced in the estuaries (Figure 4). When the larval supply is limiting oysters that settled on shells (spat on shell) are also widely used (Figure 5). In Harris Creek (Virginia) 1.25 billion oyster seed were planted on $1.5 \mathrm{~km}^{2}$ in a single year (https://oysterrecovery.org).

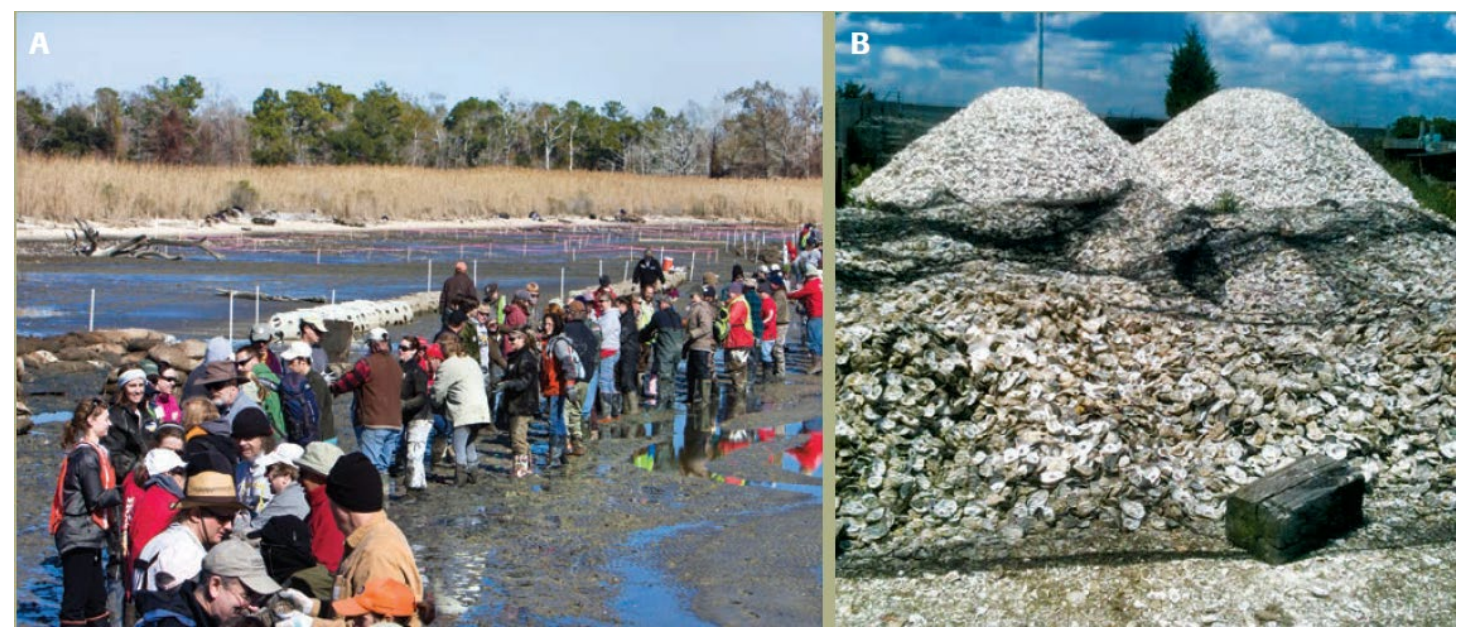

Figure 4. A. volunteers aiding in placement of shell and B. drop-off point for recycling oyster shell. From Baggett et al. (2014).

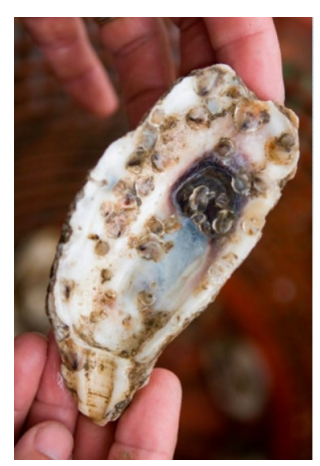

Figure 5. Crassostrea virginica spat on shell (https://oysterrecovery.org).

Based on experiences gained with other restoration projects the quality requirements for flat oysters to be used in Dutch restoration pilots are:

- disease free

- tolerance or resistance against diseases when possible

- absence of non-native species 
- good survival, growth and reproduction

- $\quad$ adapted to the local environment

- $\quad$ highest possible genetic diversity

- cost efficient.

\subsection{Desired amount of oysters}

The aim of flat oyster restoration projects is to establish a self-sustaining bed that is capable of providing valued ecosystem services. "Critical mass" is defined as the quantity of oysters required to ensure a larval abundance that is sufficient for potentially successful spat settlement and survival in the bed of origin. Estimates in the literature as to the required critical mass of flat oysters are quite diverse. According to rough estimates presented by Berghahn \& Ruth (2005), a very large oyster population in the North Sea is required - many tens of millions of individual oysters - if successful recruitment is to be achieved in the North Sea. This is linked to the openness of these systems and of the larvae, which, according to these authors, originate principally from the English Channel. The 9000 oysters that were introduced to Boothbay Harbour, Maine, USA in 1949 (Table 1) had not formed a viable population in 1957 and were largely supported by hatchery production (Loosanoff, 1962).

However, Smyth et al. (2016) have recorded that following a period of over-exploitation, a flat oyster population in Strangford Lough recovered on the basis of a limited critical mass of 100,000 flat oysters concentrated at high densities $\left(82 \mathrm{~m}^{-2}\right)$. There are many unknowns still when it comes to estimating the critical mass for flat oyster restoration in the North Sea. For this report an example is presented in Table 2. When starting with 20,000 oysters, and assuming the loss factors presented in Table 2 , it is estimated that the bed can grow to 105,000 adult oysters 3 years later. However, this is not based on actual measurements and does not take into account dispersal of the larvae away from conspecifics or absence of suitable settlement substrate. Modelling exercises have shown that larval retention differs throughout the Dutch part of the North Sea (Figure 6).

Table 2. Example of estimation of critical mass for oyster restoration pilots.

\begin{tabular}{|c|c|c|c|}
\hline Parameter & Estimated percentage/number & Source & Number of oysters \\
\hline group size & & & $2 \times 10^{4}$ \\
\hline mature females & $20 \%$ & $\begin{array}{l}\text { Joyce et } \\
\text { al., } 2013\end{array}$ & $4 \times 10^{3}$ \\
\hline eggs produced & 1 million per female & $\begin{array}{c}\text { Helm et } \\
\text { al., } 2004\end{array}$ & $4 \times 10^{9}$ \\
\hline fertilisation success & $50 \%$ & $\begin{array}{l}\text { Helm et } \\
\text { al., } 2004\end{array}$ & $2 \times 10^{9}$ \\
\hline larval survival & $1 \%$ & $\begin{array}{c}\text { Helm et } \\
\text { al., } 2004\end{array}$ & $2 \times 10^{7}$ \\
\hline spatfall survival & $5 \%$ & $\begin{array}{l}\text { Laing et } \\
\text { al } 2005\end{array}$ & $1 \times 10^{6}$ \\
\hline survival year 1 & $15 \%$ & $\begin{array}{l}\text { Laing et } \\
\text { al } 2005\end{array}$ & $1.5 \times 10^{5}$ \\
\hline survival to maturity & $70 \%$ & $\begin{array}{l}\text { Bodoy et } \\
\text { al.,1991 }\end{array}$ & $10.5 \times 10^{4}$ \\
\hline
\end{tabular}




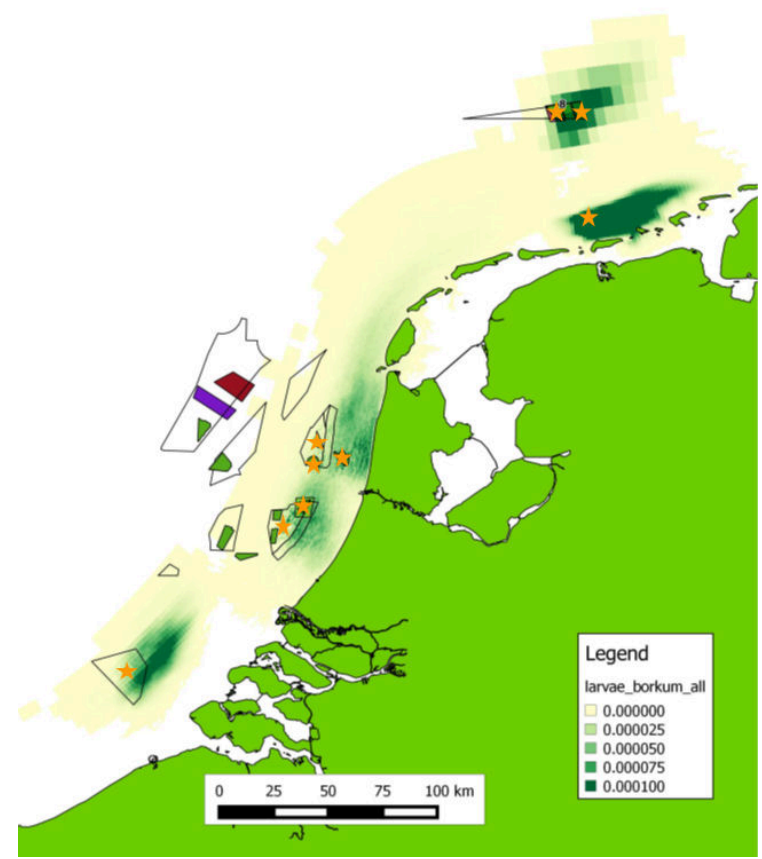

Figure 6. Simulated flat oyster larval dispersal at a number of locations in the Dutch North Sea. Orange stars are release sites of larvae by adults. The legend presents relative concentration values. From Kamermans et al. (2018a).

\subsection{Current initiatives in Atlantic Europe}

\subsection{1 the Netherlands}

Flat oyster restoration in the Dutch North Sea area started in 2014 with a number of feasibility studies funded by the government in which potential locations for restoration were identified. Smaal et al. (2015) looked at requirements for restoration involving environmental conditions for survival, growth, reproduction and recruitment of $O$. edulis. In two follow up studies wind farm locations were screened for potential restoration sites (Smaal et al., 2017, Kamermans et al., 2018a,b). Physical factors, such as bottom type and current speed, as well as biological factors, such as larval retention were taken into account.

In 2016, the first oyster restoration pilot started in the Voordelta, a nearshore area in the North Sea (Figure 7). The pilot was initiated by ARK Natuurontwikkeling (ARK foundation for Nature Development) and the World Wide Fund for Nature (WWF) and the total project was funded by several parties. A survey of potential locations based on information from the above mentioned feasibility studies led to the discovery of a mixed oyster bed with flat oysters and Pacific oysters (Crassostera gigas) (Sas et al., 2016). Present restoration efforts focus on enlarging the existing bed through introduction of shell material for larval settlement and kick starting a new bed in a nearby area that is closed for fishing (Sas et al., 2018; 2019). In 2018, around 15,000 oysters from a remaining population in the neighbouring Lake Grevelingen were transplanted to the pilot site for the establishment of a new bed. Research concerns monitoring of survival, growth, reproduction and recruitment of oysters placed in monitoring cages. Series of spat collectors are deployed during the period that larvae are available to gain insight into timing of introduction of shell material and the best type of shell material to be used (Sas et al., 2018; 2019, Didderen et al., 2019b). In addition, biodiversity development at the oyster bed location in comparison with a reference location is studied (Christianen et al., 2018; Sas et al., 2018; 2019, Didderen et al., 2019b). Programma naar een Rijke Waddenzee is investigating options to restore $O$. edulis in the Dutch Wadden Sea (https://rijkewaddenzee.nl). 


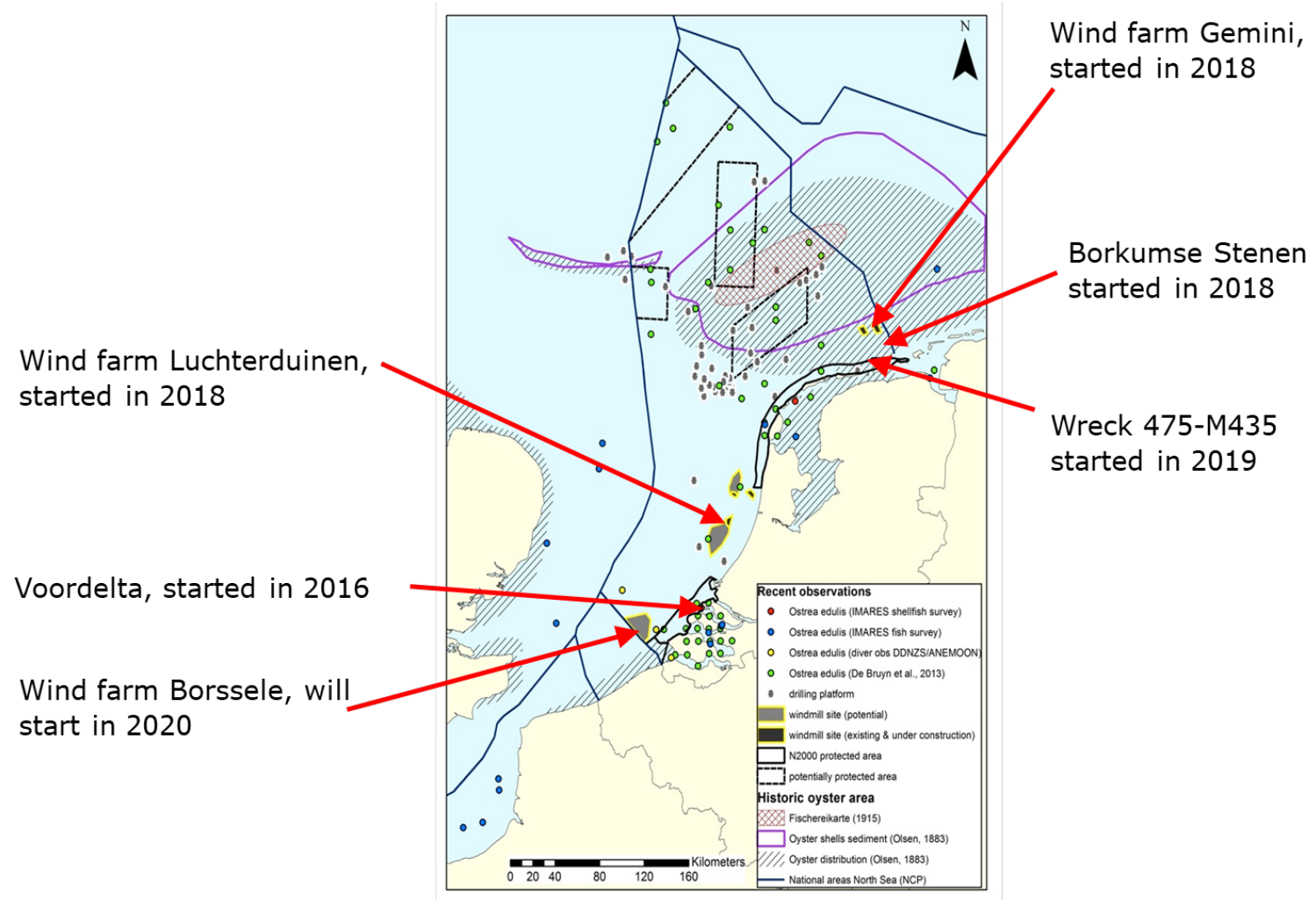

Figure 7. Dutch Ostrea edulis pilots in the North Sea.

Further offshore, three new pilot sites were established in 2018 in areas without known recent occurrences of native oysters. The largest pilot is Borkum Reef Ground, funded by WWF and ARK Natuurontwikkeling, where around 80,000 oysters were introduced (Figure 7). These oysters came from a Bonamia-free area in Norway and were treated to avoid introduction of non-native species (van der Have et al., 2018; van den Brink \& Magnesen, 2018). Survival, growth, reproduction and recruitment of oysters in monitoring cages is determined (Didderen et al., 2019a). The other two pilots take place in wind farms. In the Gemini pilot, funded by Gemini, Edmelja B.V. and WWF, around 14,000 oysters from the same Norwegian batch as Borkum Reef Ground and were deployed on the same day as Borkum Reef Ground (Didderen et al., 2018) and an additional 7,000 in spring of 2019 (Figure 7). In addition, monitoring cages were placed on the bottom. In April 2019 WWF placed around 400 Norwegian oysters on a shipwreck North of Schiermonnikoog). The initial design of the other wind farm pilot at Luchterduinen was co-financed as an EU LIFE-IP project and the subsequent implementation was funded by Eneco, Van Oord, ASN Bank, Stichting de Noordzee and Natuur en Milieu (Figure 7). In November 2018 monitoring cages were placed containing Norwegian oysters from the same source as used in Borkum Reef Ground and Gemini. Monitoring in July 2019 revealed that the cages were buried by sand and only $15 \%$ of the oysters survived. All oysters had grown before burial and the surviving oysters produced larvae which were detected both inside the mantle cavity and in the water (Didderen et al., in prep). Van Oord has two oyster restoration pilots in Borssele wind farms: Blauwwind in Borssele III/IV -and Two Towers in Borssele V - (Figure 7).

\subsubsection{Europe}

Currently, pilot projects for European flat oyster restoration outside the Netherlands are being carried out in the United Kingdom, France, and Germany. The information below was taken from Pogoda et al. (2019).

\section{United Kingdom}

In England, two restoration projects have been established in locations that historically supported large flat oyster populations. On the south coast, the Solent Oyster Restoration Project (SORP) was established after catastrophic declines in stock densities due to overfishing and the collapse of a fishery (Gravestock et al., 2014; Harding et al., 2016) (Figure 8). It aims to reseed the Solent with oysters, and restore oyster bed habitat to support a self-sustaining population. Since 2017, broodstock 
oysters are suspended in novel restoration cages from marina pontoons across the Solent to increase reproduction and provide a source of larvae to populate the surrounding seabed. Monitoring of growth, health, survival, reproduction and recruitment is ongoing. In addition, seabed cages containing native oysters were deployed to test their physiological performance and ecosystem service provision at different elevations above the seabed. Effects of density on survival, growth, reproduction, benthic structure and biodiversity are assessed estuary-wide to provide data for future seabed deployment within designated European and UK marine sites.

On the east coast, The Essex Native Oyster Restoration Initiative (ENORI) was established in 2011 as a collaboration between oyster fishermen, nature conservation organisations, academia and government regulators (Figure 8 ). It is restoring selfsustaining populations of native oysters within a Marine Conservation Zone across the Blackwater, Roach, Crouch and Colne estuaries. Broodstock oysters and substrate (shell material) were deployed to the seabed to increase reproduction and recruitment of a nationally important breeding population. ENORI has created an adaptive management fisheries plan to recover native oyster populations which may allow a sustainable fishery.

In Wales, a feasibility study and baseline surveys identified the need for native oyster restoration (Woolmer et al., 2011) (Figure 8). In 2019, the Wales Native Oyster Restoration Project has been established by Natural Resources Wales. It will focus on a series of restoration plots and will address fundamental sitespecific questions relating to survival, recruitment, density effects, and the impacts of Bonamia disease and non-native species. Associated habitat and biodiversity enhancement will also be assessed.

In Scotland, oyster restoration feasibility studies started in the late 1990s and have recently gained momentum (Shelmerdine and Leslie, 2009; Fariñas-Franco et al., 2018). Oysters have been extirpated for over one hundred years in many sites (Thurstan et al., 2013; Fariñas-Franco et al., 2018). In 2013 the Dornoch Environmental Enhancement Project (DEEP) was initiated (Figure 8). After a feasibility study (Fariñas-Franco et al., 2018), Scottish oysters were successfully translocated to the Dornoch Firth in 2017. Monitoring of growth, health, survival, reproduction and recruitment is ongoing (Sanderson, in prep.). Supporting research projects have been established to examine the contribution oysters make to blue carbon storage as well as the behaviour and therefore likely destinations of oyster larvae from the restoration sites (Rodriguez-Perez et al., 2019). Furthermore, substrate (shell material) was deployed to the seabed to increase recruitment by creating a series of "reefs" and "beds". These habitats are being populated with oysters, grown by suppliers from across Scotland. Additional restoration projects are planned in Plockton, Ardfern and Loch Ryan.

\section{France}

In France, the flat oyster was once a dominant species in coastal waters, but is now confined to only a few localized environments. Since 2018, the Flat Oyster Recovery project (FOREVER) promotes the reestablishment of native oysters in Brittany (France). It will provide a regional inventory of the main native oyster beds and a detailed analysis of the ecology and dynamics of the still remaining beds in the Bays of Brest and Quiberon (Figure 8). General functional status will be evaluated by density, size structure, mortality, health and genetic status, as well as by a better understanding of the recruitment dynamics within an oyster bed (larval abundance, larval behaviour, settlement processes). Associated benthic diversity and trophic interactions will also be assessed. Restoration and management measures will be implemented in partnership with local stakeholders (fisheries and shellfish farming bodies, regional government authorities, environmental management organizations, e.g. Natura 2000). The development of substrate structures is an important goal to increase recruitment. 


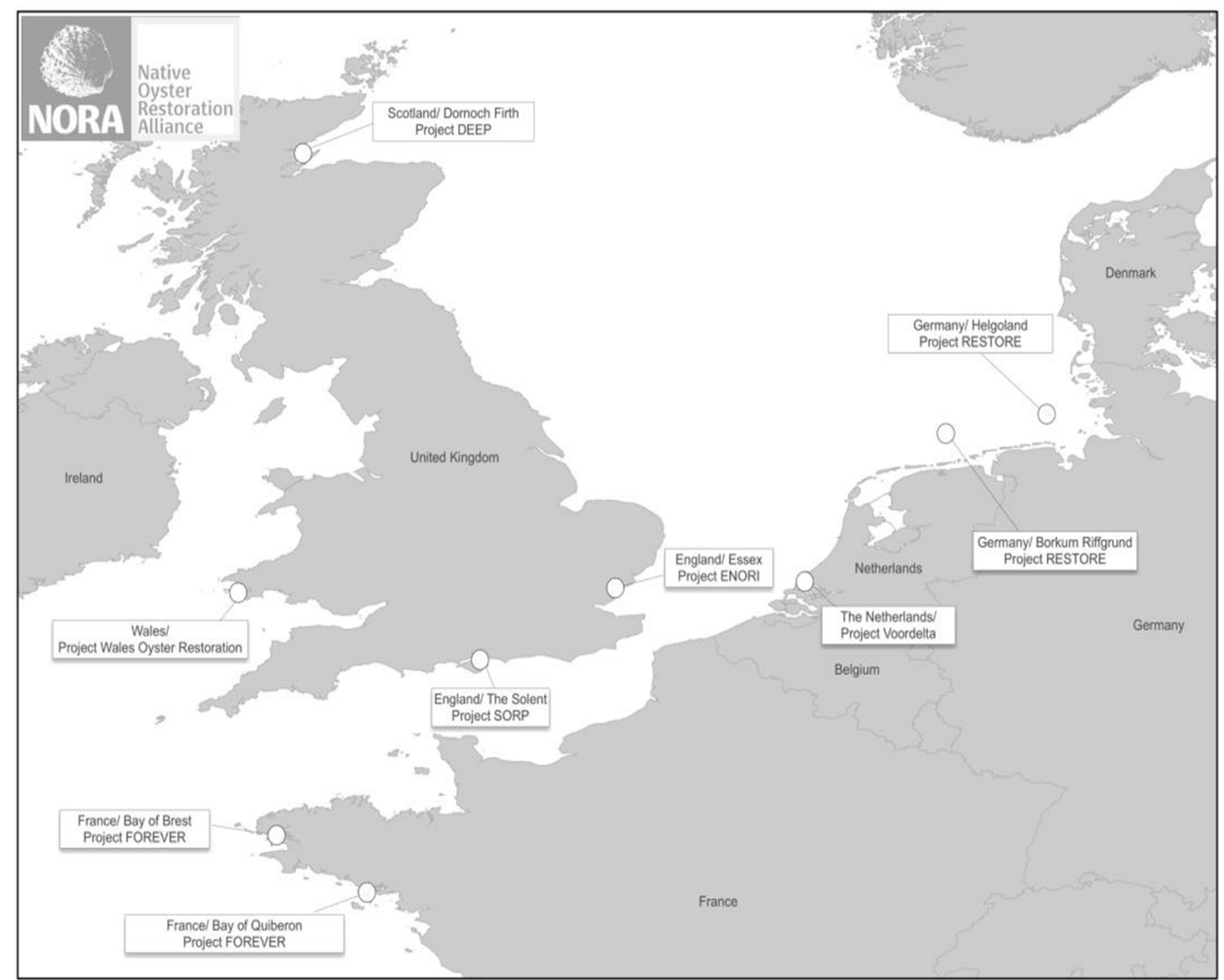

Figure 8. Currently planning or implementing European restoration pilot projects or nature conservation measures with Ostrea edulis. From Pogoda et al. (2019). The Dutch off-shore pilots are missing on this map.

\section{Germany}

In the German Bight, the European flat oyster is believed to be functionally extinct since the 1950s. A feasibility study (Gercken and Schmidt, 2014) and further restoration projects were initiated by the German Federal Agency for Nature conservation (BfN). Since 2016, the testing and development project RESTORE aims at the sustainable restoration of the European flat oyster Ostrea edulis in the German North Sea (Figure 8). Two experimental sites are located within the historical distribution around the Island of Helgoland. Monitoring of growth, health, survival, reproduction and recruitment is ongoing. Field experiments with juvenile oysters show excellent growth and condition (Pogoda, 2019; Merk et al., in prep). Furthermore, adequate restoration sites have been identified and will be established in the Marine Protected Area and Natura 2000 site Borkum Riffgrund in 2019. Associated benthic diversity and trophic interactions will also be assessed. Sufficient supply of healthy and certified seed oysters was defined as a critical limiting factor for long-term restoration. The project PROCEED addresses biological and technological research questions to establish a healthy broodstock and a sufficient seed oyster production for native oyster restoration. Furthermore, it focuses on knowledge transfer and it will raise and improve a general awareness for this former native species and the importance of its restoration. The native oyster is characterized as an ecological key-player and oyster reefs are used as an example to explain biodiversity as a stabilizing factor for the wider ecosystem and to underline the general significance of ecosystem services.

\subsubsection{Native Oyster Restoration Alliance (NORA)}

In November 2017, the Native Oyster Restoration Alliance (NORA) was formed by partners from science, technology, nature conservation, consultancies, commercial producers and policy-makers (https://noraeurope.eu/). The alliance has met twice: in November 2017 in Berlin, where it was formed, and in May 2019 in Edinburgh. The NORA network aims to develop best practice recommendations and promote multidimensional knowledge and technology exchange, enhance scientific and practical progress in flat oyster restoration, such as in project planning and permitting, seed oyster production, disease management and monitoring. It also focuses on joint funding opportunities and the potential development of national and international regulatory frameworks. The main motivation behind NORA is to facilitate the restoration of native oyster habitat within its historic 
biogeographic range in the North Sea and other European seas along with the associated ecosystem services; services such as enhancing biodiversity, including enhanced fish stocks, nutrient cycling and sediment stabilization. In Berlin, NORA members agreed on a set of joint recommendations and strongly advise that any restoration measure should respect and apply these recommendations. The Berlin Oyster Recommendation is presented in Pogoda et al. (2019) and copied below.

\section{Berlin Oyster Recommendation}

\section{Produce sufficient oysters for restoration of oyster reefs}

Background: Sufficient seed oyster supply is a key limiting factor for native oyster restoration projects in Europe. Translocation between sites of seed oysters or any other size classes from wild beds should be discouraged to avoid increasing the pressure on still existing wild beds and reduce the risk of spreading invasive species and disease.

Recommendation: Action should be undertaken to support existing hatcheries, spatting ponds and spat collector techniques and to establish new hatcheries and spatting ponds for the production of robust and genetically diverse Ostrea edulis seed. Broodstock sanctuaries should be established and used for local reinforcements.

\section{Identify and create suitable sites for restoration of oyster reefs}

Background: Restoration projects to recover Ostrea edulis habitat will only succeed in areas where environmental conditions are suitable and no bottom disturbance, e.g. bottom trawl fishery, occurs. Recommendation: Sufficient undisturbed and suitable areas should be identified for the restoration and protection of Ostrea edulis in all regions of its indigenous range. This includes the restoration of suitable substrate in some areas. It will be important to identify and afford protection to several major sites in Europe, where:

- Ostrea edulis was recorded previously but has disappeared ("reintroduction" sites)

- Ostrea edulis is still present, but in very low density ("reinforcement" sites)

- Ostrea edulis is abundant with sufficient reproduction and settlement for the habitat to persist in the long term ("conservation" sites)

\section{Provide suitable substrate for successful recruitment}

Background: Sustainable success of restoration efforts depends on successful recruitment and, therefore, not only on the supply of sufficient larvae but also on the availability of suitable substrate. After their planktonic phase, oyster larvae prefer to settle on oyster shells. Suitable and abundant settlement substrate is a major limiting factor for Ostrea edulis recovery in areas with natural spatfall and of high importance for sustainable restoration.

Recommendation: Extraction of Ostrea edulis shells from the marine environment for other usages should be stopped. The addition of suitable substrate will ease recruitment of larvae.

\section{Respect Bonamia-free areas}

Background: In many European ecoregions, the invasive parasite Bonamia is present today. Bonamia ostreae is an invasive protozoan parasite infecting haemocytes of native oysters and inducing physiological disorders, potentially resulting in the eventual death of the animal. High mortality rates have been described for cultivation sites with high densities of oysters and elevated summer temperatures. Despite this, tolerant populations appear to exist in France, The Netherlands, Spain and Ireland. Genetic studies have demonstrated that tolerance to this parasite is heritable and genomic studies have identified QTLs and expressed genes associated with tolerance.

Recommendation: Research to better understand the biology of the Bonamia parasite and infection dynamics should be encouraged. Biosecurity protocols must be strictly followed in Bonamia-free areas. Any area where there is functional extinction of Ostrea edulis should be treated as a Bonamia-free area. Techniques should be sought to take advantage of any disease tolerance that has developed in broodstock from high disease load areas, without transferring pathogens.

\section{Create common monitoring protocols}

Background: Native oyster restoration is in its infancy in Europe. There are numerous outstanding questions regarding best practice for restoration of the European native oyster. A shared monitoring protocol will allow lessons and outcomes to be shared between all European restoration efforts. This 
will reduce duplication of effort and ensure that progress towards successful restoration is as rapid as possible.

Recommendation: Monitoring protocols that will provide comparable results for projects throughout Europe and for restored sites should be developed and followed. Where possible, monitoring should include the assessment of ecosystem services on a habitat and ecosystem scale.

\section{Preserve genetic diversity}

Background: The preservation of the genetic diversity of European native oyster populations is of central importance for maintaining its ability to adapt to changing environmental conditions, stress factors (disease, climate change) and to facilitate the long-term survival of native oyster habitats in Europe.

Recommendation: Established hatchery and pond production protocols should be adapted to preserve the extant genetic diversity of native oysters in Europe. 


\section{$4 \quad$ European flat oyster supply}

In this chapter available methods to produce or acquire flat oysters are described. The production methods include hatchery/nursery, ponds, spat collectors, culture in the field and harvest from wild beds. In addition, an overview of flat oyster producers in Europe is given.

\subsection{Production methods}

\subsubsection{Hatchery and nursery}

In a hatchery, seed is produced in two steps: larvae and spat are produced indoors, grow-out up to seed size generally takes place in an outdoor nursery. Depending on the grow-out system, spat can also be directly transferred to the grow-out site.

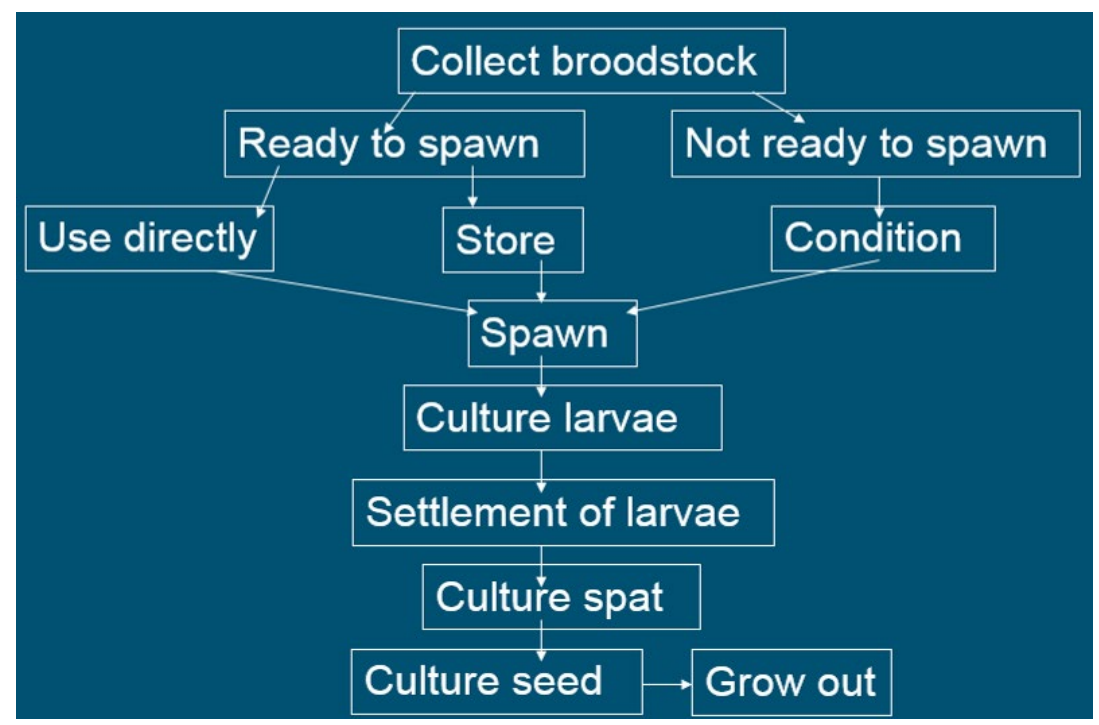

Figure 9. Summary of hatchery process.

The hatchery process is summarised in Figure 9. The first step is to collect the parents (broodstock) from natural or cultured populations. These oysters can either be ready to spawn, or not ready to spawn. When they are ready to spawn, the oysters can be used directly for spawning. Alternatively, they can be stored in tanks at low temperatures without food where they can be kept in spawning condition up to a few months. When they are not ready to spawn conditioning is in tanks needed which involves a gradual temperature increase while providing food over a period of 4 to 6 weeks. Fertilisation takes place during conditioning. Release of larvae is detected by directing the outflow of the conditioning tank over a sieve which is checked daily for the presence of larvae. Development to larvae occurs within $48 \mathrm{~h}$. During this phase the larvae are reared in static or flow-through systems (Figure 10) and fed live microalgae. Generally, the hatchery cultures these microalgae on site (Figure 11). The larval phase lasts around 2 weeks. After this period, they undergo metamorphosis by settling onto a substrate. In commercial hatcheries this is cultch, shells grinded to sand grain size. This is done because the end product should be single oysters. Selecting the best settlement substrate for restoration projects is under development, but shells seem a good choice.

Bottle necks still remain in flat oyster seed production in hatcheries compared to other shellfish species. This concerns relatively little control over broodstock conditioning, sudden mortality of larvae during the rearing process and high mortality during metamorphosis. One of the critical steps in hatchery production is broodstock conditioning, which accelerates gonadal development to generate a healthy cohort of larvae all year round. The conditioning of $O$. edulis broodstock may be improved by manipulating several external factors such as temperature, food supply (diet, food ratio, etc.), and 
photoperiod (Maneiro et al., 2016; Maneiro et al., 2017). However, seasonality and the frequency of bivalve reproductive cycle affecting the initial physiological condition vary in relation to geographical distribution. Although culture techniques for efficient husbandry have been developed, epizootic episodes caused by known and unknown pathogenic species constitute the main bottle neck during the early stages of larval development leading to high mortality rates and the rapid loss of production batches (Prado et al., 2005; Dubert et al., 2017). Optimal conditions for growth and development of bivalve larvae in hatcheries (densities, temperature, load of organic matter, etc.) enhance the growth and multiplication of bacteria and the accumulation of their metabolites (Brown \& Tettelbach, 1988; Araya et al., 1999). Larvae are more susceptible to vibriosis caused by Vibrio bacteria than adults since the resistance to bacterial infection significantly increases with age of the bivalves (Gómez-León et al., 2008). In order to stabilize and increase larval survival, further development of the available technologies to overcome bacterial infections are needed. Robert el al. (2017) applied the use of flowthrough systems to decrease larval mortalities. While Dubert et al. (2017) suggested the use of recirculation systems (RAS) as a way to provide a better water quality control. The settlement phase for bivalve larvae is particularly important, as the larvae are unable to metamorphose successfully unless they are attached to a suitable substrate (Wieczorek \& Todd, 1998). The amount of food consumed by the larvae during their pelagic life is essential, as they must store sufficient reserves to meet the energy demands required during metamorphosis (González-Araya \& Robert, 2018).

Spat rearing is carried out in a nursery where the oysters are kept on sieves with running seawater (Figure 12). The small oysters (spat) are usually reared indoors and fed microalgae that are cultured indoors (Figure 11). Larger oysters (seed) are reared outdoors with algae that are cultured in open ponds (Figure 13). The final product of a hatchery is seed. Different sizes of seed are produced. This is indicated by the size of the mesh that retains the seed, e.g. T8 is seed that stays on a 8-mm sieve. The larger the seed size, the higher the price. The process from broodstock conditioning to T8 seed takes around 5-6 months. The seed is used for grow out to commercial size oysters in the field.

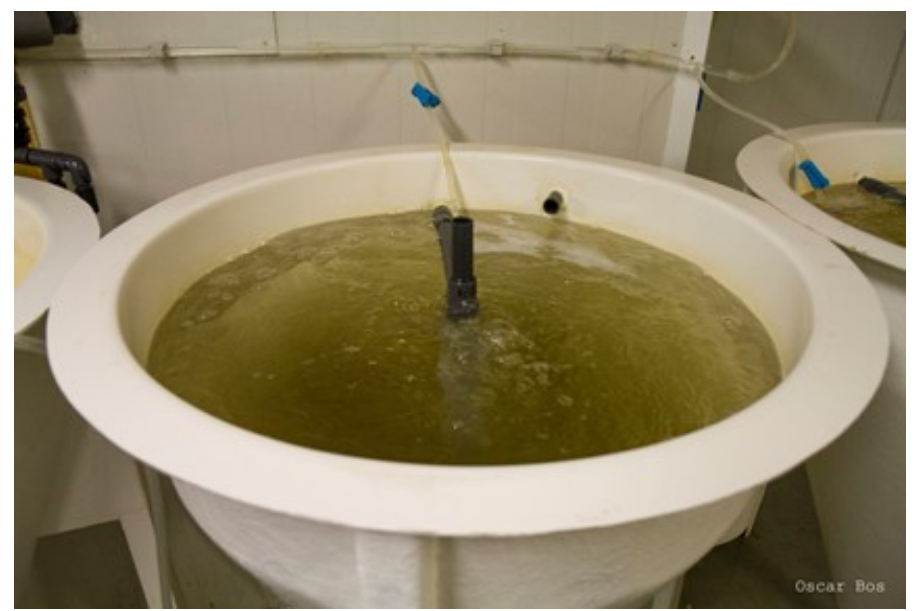

Figure 10. Larval rearing tank at the hatchery of Roem van Yerseke (picture Oscar Bos).

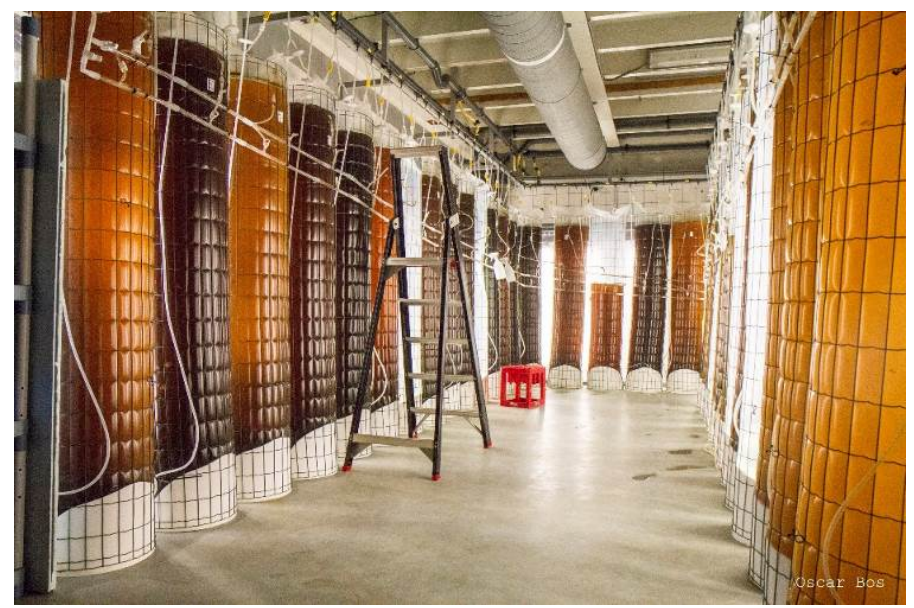

Figure 11. Algae culture at the hatchery of Roem van Yerseke (picture Oscar Bos). 


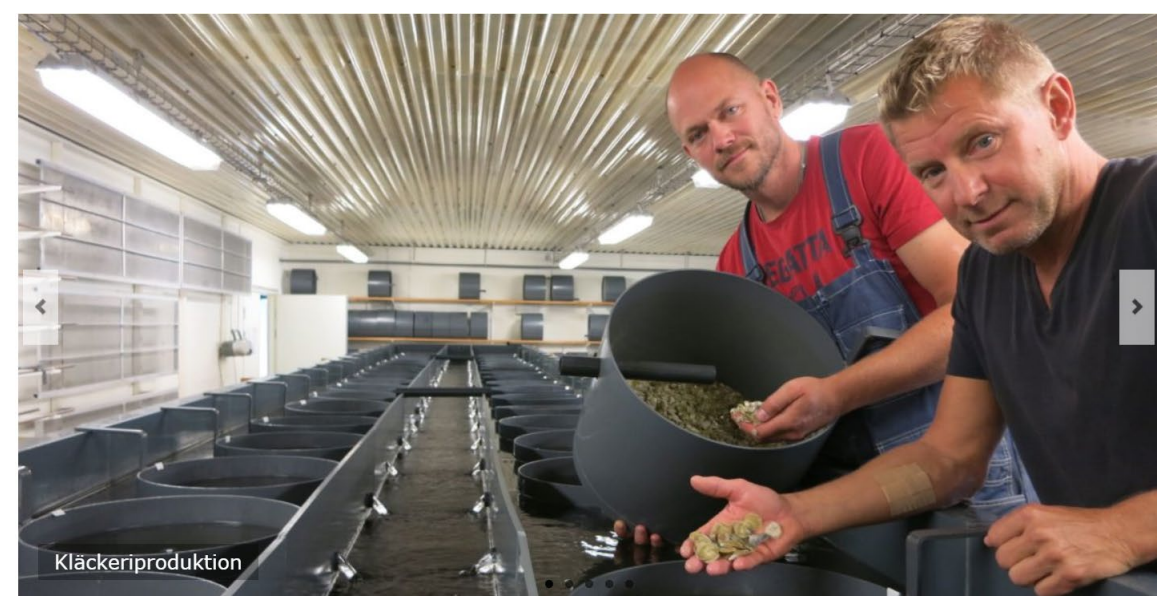

Figure 12. Indoor nursery of Ostrea in Sweden (Ostrea Aquaculture http://aquaculture.se/).
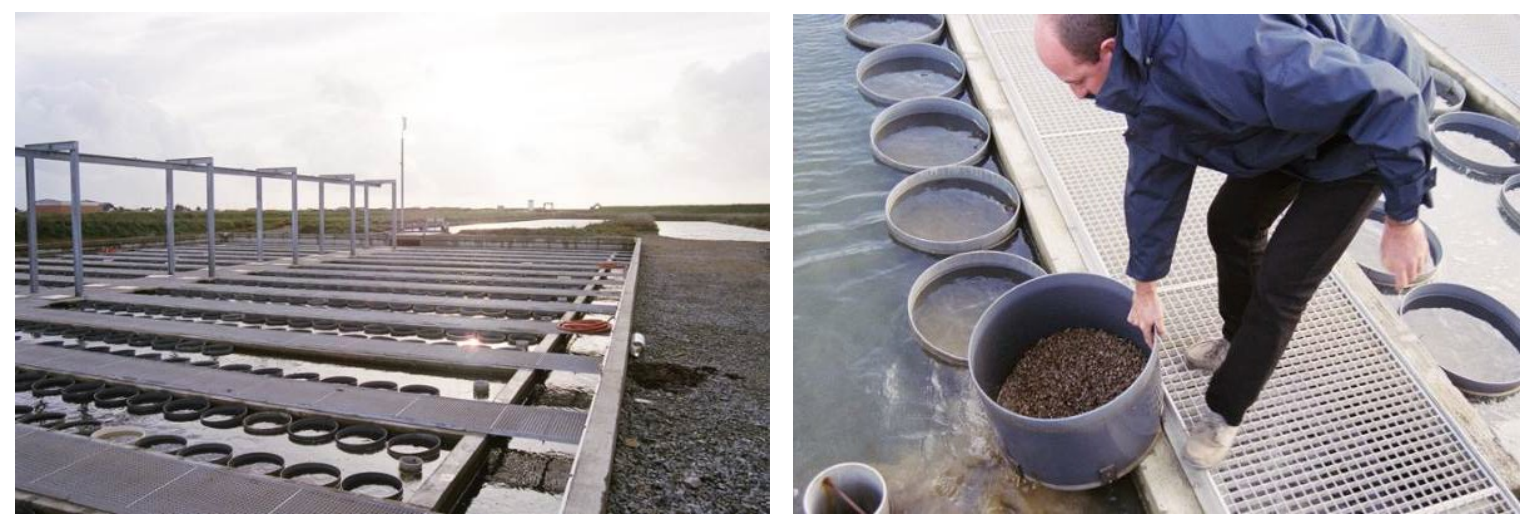

Figure 13. Outdoor nursey with algal pond in background (left) and close up of sieve with Pacific oyster seed (right) in the Vendée area in France (pictures Pauline Kamermans).

A cheaper nursery system is a floating upwelling system (FLUPSY) as shown in Figure 14. A FLUPSY is placed outdoors. Water with natural occurring algae is pumped through the oysters. The oysters in a FLUPSY are fed with algae occurring in natural waters. So no algae is cultured, therefore the operational costs will be much lower than an inland upwelling system. Disadvantages of a FLUPSY system are the disability to optimize any parameters (temperature, amount of feed, $\mathrm{pH}$ etc.). In general, it will take longer for the oysters to reach the desired size (less feed than an inland upwelling system) and the system is placed outdoors, so the oysters are exposed to natural environment.

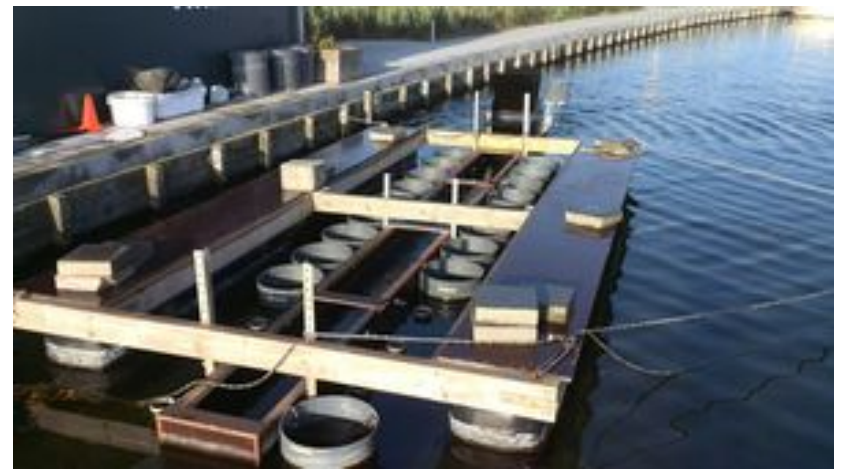

Figure 14. FLUPSY of Roem van Yerseke (picture Wouter Bareman).

\subsubsection{Ponds for spat and adults}

The use of ponds to produce flat oyster spat was first described by Walne (1974). He used concrete basins of $25 \mathrm{~m}$ long, $10 \mathrm{~m}$ wide and $2 \mathrm{~m}$ deep. Nowadays, butyl-lined ponds are more common (Figure 15). Ready to spawn broodstock (600 individuals) is introduced in the basins and presence of larvae is monitored daily. As soon as larvae are present water exchange with the nearby estuary is stopped. To monitor settlement of spat unglazed ceramic tiles are used. When $25 \%$ of the larvae are larger than $250 \mu \mathrm{m}$ settlement substrate is introduced. This used to be tiles, but nowadays empty mussel shells in 
oyster bags are more commonly used. Around 7-14 days after settlement the water can be exchanged again. Natural seawater is used, therefore production of algae is not needed. However, natural fluctuations in food supply can occur, reducing the success rate compared to hatchery production In addition, production is only possible in the summer months. In the example of Walne (1974) 600 broodstock oysters produced 218 million larvae, of which 9 million survived to spat.

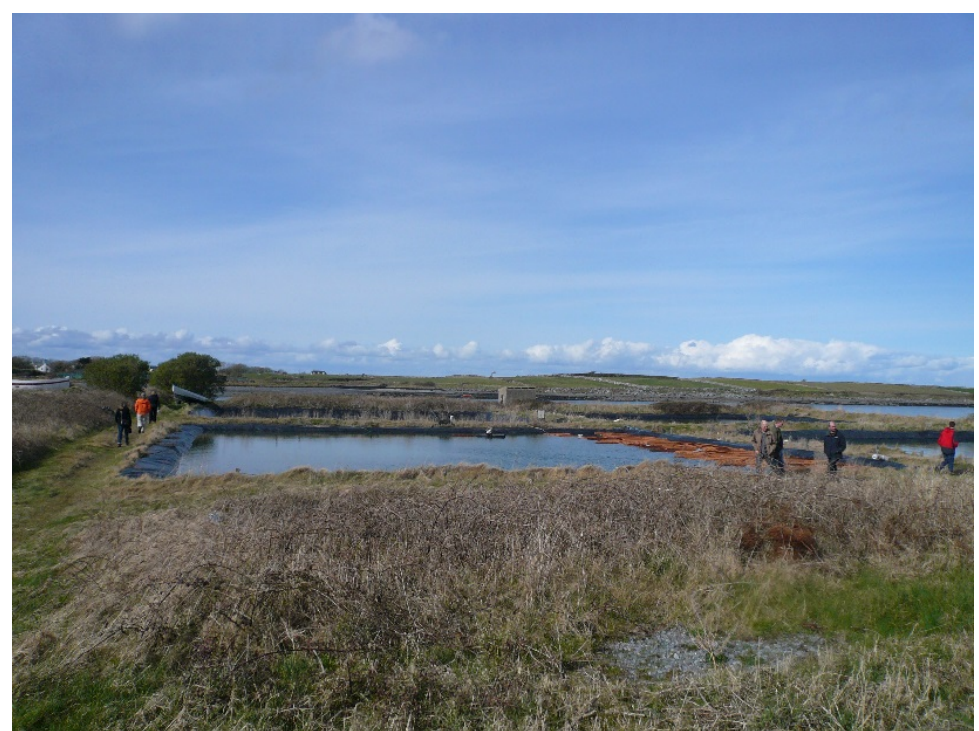

Figure 15. Flat oyster pond at Cartron Point, Ireland (picture Pauline Kamermans).

In Norway, two types of ponds are used for flat oyster cultivation. The breed polls are 5-10 m deep, 15 ha with restricted water exchange and stratification and contain around 1000-6000 oysters. They are used for larval release and collecting spat. The spat polls are larger, up to $20 \mathrm{~m}$ deep and 40 ha and in direct exchange with outside fjord (Figure 16). They are used for grow out and fattening (Lillias et al., 2010).

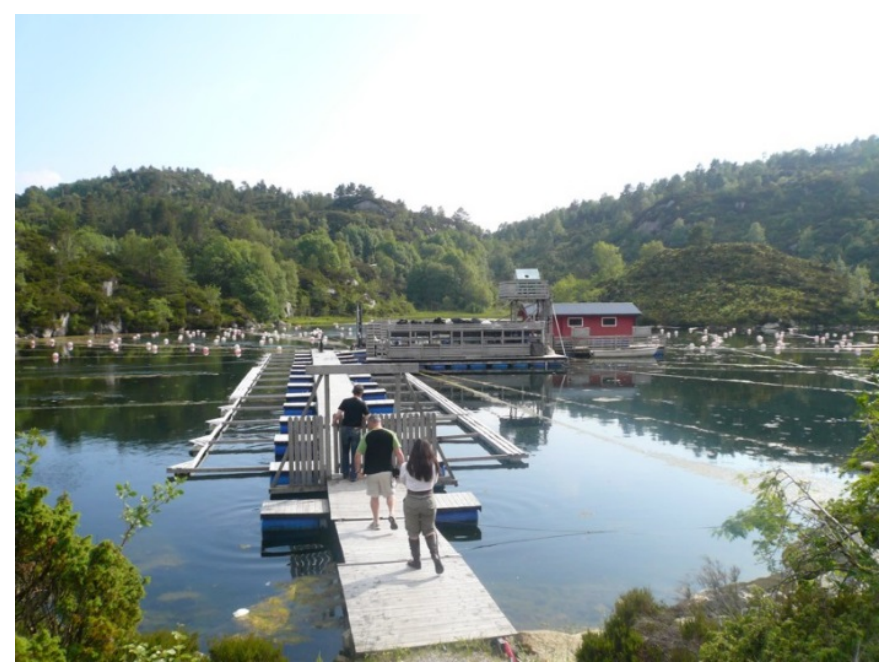

Figure 16. Spat poll of Bǿmlo Skjell, Norway (picture Pauline Kamermans).

\subsubsection{Spat collectors and culture in the field}

Oyster larvae need hard substrate to settle on. When hard substrate is provided at the time when oyster larvae are settling, oyster spat can be collected. A common substrate used by oyster farmers is stacks of Chines hats (Figure 17a). Oyster spat is easily removed from the collectors by popping them inside out in with a specialised machine (Figure 17b). In the Netherlands, empty mussel shells are placed on bottom plots in summer to collect spat. Shells with spat a harvested the following spring (Figure 18). In Lake Grevelingen and the Voordelta several experiments were carried out to test different spat collectors for flat oysters (Kamermans et al., 2004; van den Brink et al., 2013; Sas et al., 2018; 2019, Didderen et al., 2019b). Chinese hat collectors, mussel- and oyster shells yielded good results. Furthermore, results show that there are more species that like to settle on hard 
substrate and fouling can be a major problem especially in submerged collectors. Therefore, best practice is to present the collector shortly before settlement, which is two weeks after the peak in oyster larvae (van den Brink et al., 2020). A recent analysis of long-term data series indicates that the timing of larval release can be predicted based on the development of the temperature (Maathuis et al., 2020).
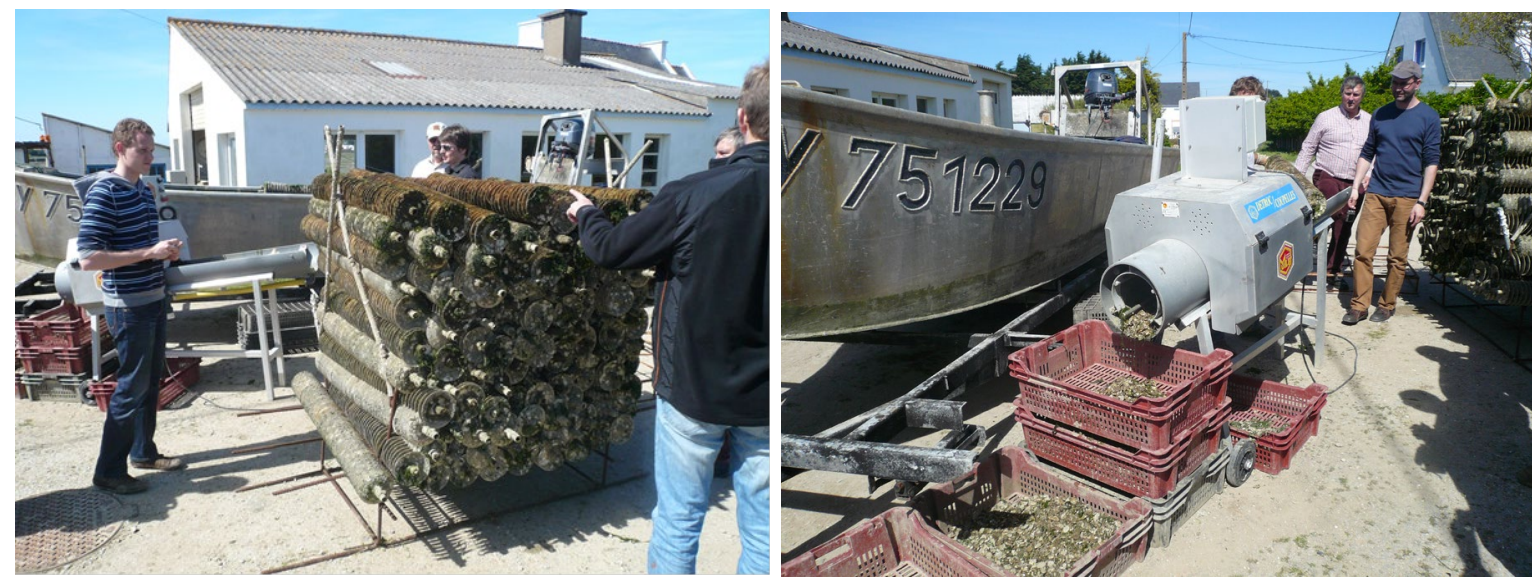

Figure 17. Spat collecors (stacks of Chinese hats) (left) and machine to remove spat (right) at Pacific oyster culture farm in France (pictures Pauline Kamermans).

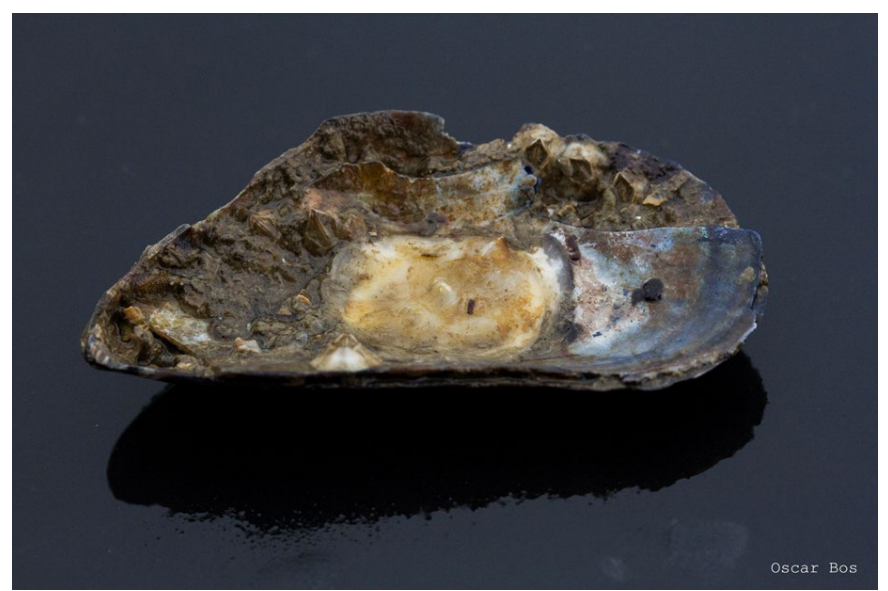

Figure 18. Flat oyster spat on mussel shell (picture Oscar Bos).

Flat oyster spat is cultured up to market size in off-bottom structures such as bags on tressles or baskets on long-lines (Figure 19), or on bottom plots.

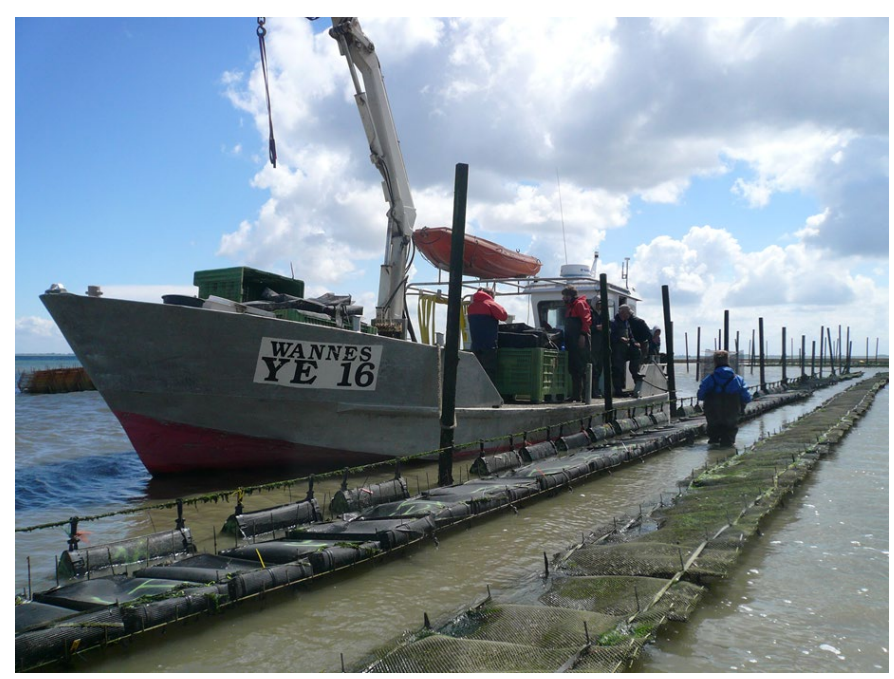

Figure 19. Baskets on long-lines (furthest left) and bags on tressles in off-bottom farm in the Oosterschelde (picture Pauline Kamermans). 


\subsubsection{Harvest from wild beds}

In a number of European countries flat oysters are harvested from wild beds. In Denmark, France and Spain this is done with dredges (Figure 20), while in Sweden and Norway the oysters are hand-picked, either from areas that emerge at low tide, or with divers from permanently submerged areas (Figure 21).

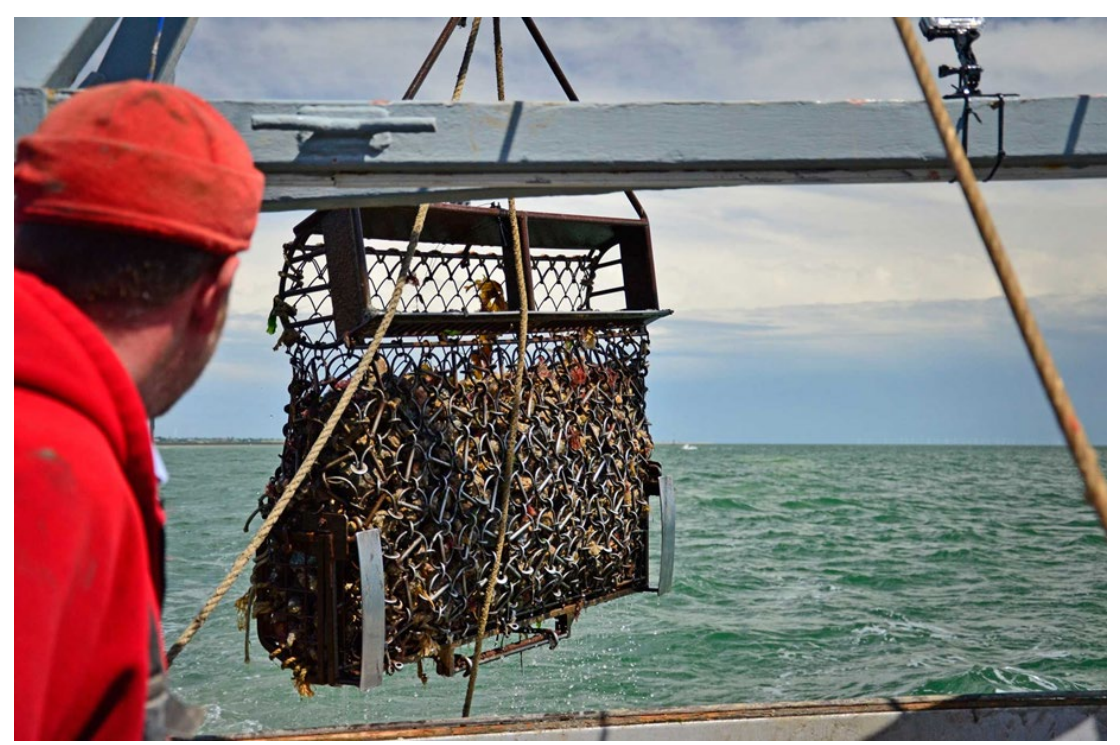

Figure 20. Oyster dredge (picture https://www.kentandessex-ifca.gov.uk/im-interested-in/fishingcommercially/dredging/oysters).

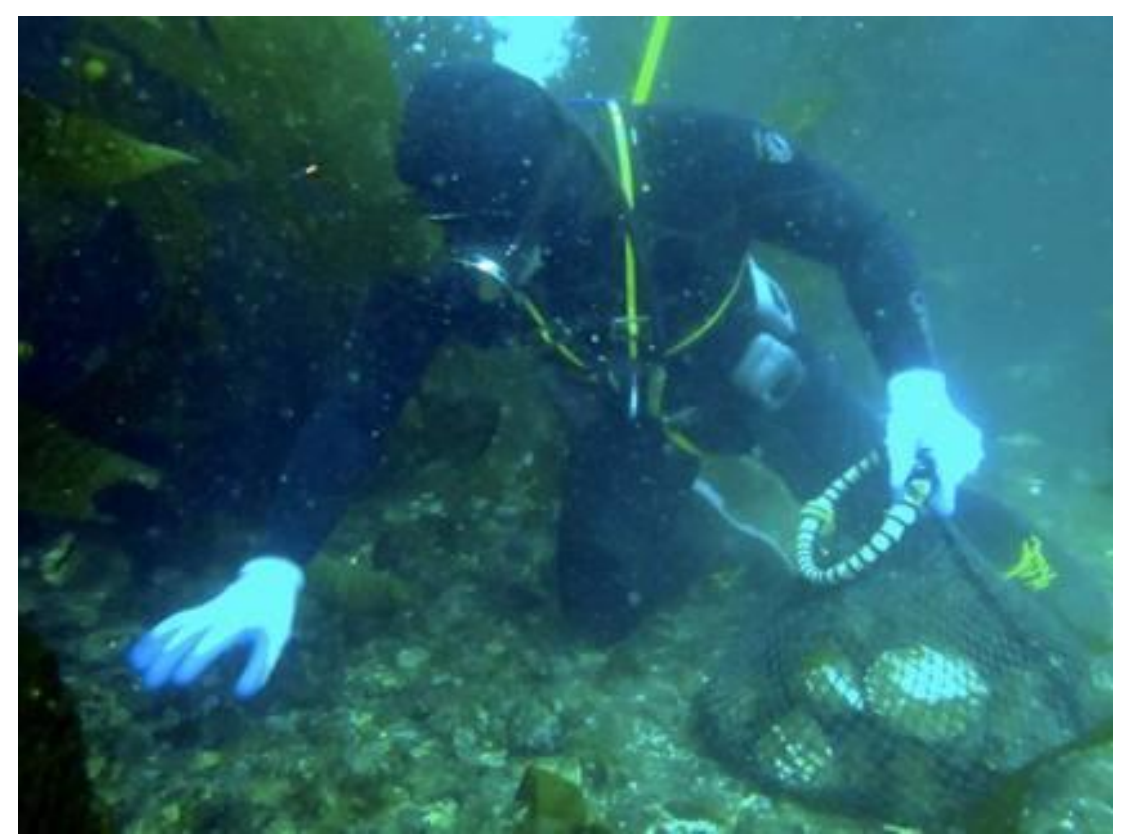

Figure 21. Collecting flat oysters with divers (picture bbc.co.uk).

\subsection{Producers}

Production of flat oysters for consumption takes place in 12 countries in Europe (Table 3). This includes harvest from natural beds and on- and off-bottom culture starting with spat which originates from spat collectors, hatchery - or pond production. France is the largest producer with 758 tonnes and the Netherlands the fourth with 350 tonnes. Assuming a weight of 80 gram for a market size flat oyster, this amounts to a production of 9.5 million and 4.4 million individuals respectively in 2017. Table 4 gives an overview of flat oyster hatchery and pond producers in Atlantic Europe. There are ten commercial hatcheries that produce flat oyster spat for farmers (Scalpro, Ostrea, Roem van Yerseke, Seasalter Walney, Tralee Bay Hatchery, Cartron Point Shellfish, Novostrea Bretagne, Ostrea Marinove, Aqua Nostra and Ostreida). Three of these - Scalpro, Seasalter Walne and Ostreida - are presently not 
producing flat oysters, but Seasalter Walne is planning to start again soon. In addition to the commercial hatcheries a number of research based organisations produce flat oyster spat (Danish Shellfish Center since 2002, NIOZ in 2018 and Stichting Zeeschelp started in 2019) or are planning to do so soon (PROCEED project of Alfred Wegener Institute). Spatting ponds are used by four companies (Danish Oysters, Atlantic Shellfish, Tralee Bay Hatchery and Cartron Point Shellfish) and one has started this year (EDMELJA). Pond production of adult flat oysters is carried out by three Norwegian companies (Scalmarin, Bømlo Skjell, Storestraumen østers Innerøyen). The disease status (with)in EU Member States and Norway is regulated based on Commission Decision 2009/177/EC and can be found in table 5 .

Table 3. European production of flat oysters for consumption, FAO data (www.fao.org).

\begin{tabular}{|c|c|}
\hline Country & Production in 2017 (t) \\
\hline France & 758 \\
\hline Ireland & 587 \\
\hline Spain & 366 \\
\hline the Netherlands & 350 \\
\hline Croatia & 237 \\
\hline Denmark & 150 \\
\hline United Kingdom & 59 \\
\hline Montenegro & 17 \\
\hline Norway & 17 \\
\hline Greece & 10 \\
\hline Sweden & 8 \\
\hline Portugal & 1 \\
\hline
\end{tabular}


Table 4. Flat oyster hatchery and pond producers in Atlantic Europe. Data from 2018, updated in 2020 by Renate Olie of The Rich North Sea.

\begin{tabular}{|c|c|c|c|c|c|}
\hline Country & Name & Type of production & Capacity per year & Disease status & Comments \\
\hline Norway & $\begin{array}{l}\text { Storestraumen østers } \\
\text { Innerøyen }\end{array}$ & Pond production & 500.000 adult flat oysters & No diseases & $\begin{array}{l}\text { Cultivated from } 1880 \text { s, testing } \\
\text { by IMR. }\end{array}$ \\
\hline Norway & Sunnhordland Havbruk & Pond production & No production in 2020 & Bonamia free & $\begin{array}{l}\text { Adults, testing by IMR. Will give } \\
\text { update if/what they could } \\
\text { deliver in } 2021\end{array}$ \\
\hline Norway & Scalpro A/S & Hatchery & $\begin{array}{l}\text { Not in } 2020 \text { but } 10-20 \text { million } \\
\text { spat on shell in } 2021\end{array}$ & No diseases & $\begin{array}{l}\text { Now producing scallops. } \\
\text { Measurements done by IMR }\end{array}$ \\
\hline Sweden & Ostrea & $\begin{array}{l}\text { Hatchery, start-up. } \\
\text { Goal is adults and spat }\end{array}$ & $\begin{array}{l}\text { Not much in } 2020 \text { due to } \\
\text { corona, next year's plan is } 15- \\
20 \text { million spat up to } 5 \mathrm{~mm} \text {. }\end{array}$ & $\begin{array}{l}\text { No diseases detected in } \\
\text { the Koster area }\end{array}$ & Started in 2008 \\
\hline Denmark & Danish Oysters (Aquamind) & Spatting pond & $\begin{array}{l}\text { Up to } 10 \text { million spat on shell } \\
\text { (sometimes nothing, sometimes } \\
\text { a few million), can also deliver } \\
\text { adults }\end{array}$ & Bonamia positive & One production per year \\
\hline Denmark & Danish Shellfish Center & Hatchery & $\begin{array}{l}\text { In } 2020<1 \text { million, next year } \\
\text { could be increased (producing } \\
\text { spat, trying spat on shell) }\end{array}$ & $\begin{array}{l}\text { Bonamia positive area, } \\
\text { currently testing protocol, } \\
\text { no Marteilia in the area }\end{array}$ & $\begin{array}{l}\text { Started in } 2002 \text {, currently } \\
\text { building a new hatchery to } \\
\text { increase volume. No certificate, } \\
\text { get PCR results from their } \\
\text { laboratory }\end{array}$ \\
\hline Germany & PROCEED - AWI & Hatchery & $\begin{array}{l}\text { Can deliver spat on shell and } \\
\text { seed (just starting can't say } \\
\text { capacity, depends also on } \\
\text { orders) }\end{array}$ & No diseases & $\begin{array}{l}\text { Under construction, broodstock } \\
\text { from Scotland, tested in France }\end{array}$ \\
\hline Netherlands & Roem van Yerseke B.V. & Hatchery & $\begin{array}{l}1-7 * 10^{\circ} \text {, can deliver spat on } \\
\text { shell }\end{array}$ & $\begin{array}{l}\text { Bonamia positive and } \\
\text { Bonamia free }\end{array}$ & $\begin{array}{l}\text { Started in 2006, Irregular } \\
\text { production }\end{array}$ \\
\hline Netherlands & NIOZ & Hatchery & 50.000 & Bonamia free & Produced in 2018 \\
\hline Netherlands & Stichting Zeeschelp & Hatchery & unknown & $\begin{array}{l}\text { Bonamia positive and } \\
\text { Bonamia free }\end{array}$ & Started in 2020 \\
\hline Netherlands & EDMELJA B.V. & Spatting pond & unknown & In Bonamia positive area & Will start in 2021 \\
\hline UK & Seasalter Walney Ltd & Hatchery & $\begin{array}{l}\text { In theory } 10 \text { s of millions, } \\
\text { depends on orders. Made } 2.5 \\
\text { million in } 2019 \text {, but sold only } \\
\text { few hundred thousand }\end{array}$ & No diseases & Cefas measures $2 \mathrm{x}$ a year \\
\hline UK & Northbay Innovations Ltd & Hatchery & 5 million $(8-10 \mathrm{~mm})$ by end 2022 & No diseases & $\begin{array}{l}\text { Building completed April/May } \\
\text { 2021. Bonamia-free certificates }\end{array}$ \\
\hline
\end{tabular}




\begin{tabular}{|c|c|c|c|c|c|}
\hline & & & & & $\begin{array}{l}\text { can be issued by Scottish } \\
\text { Authorities (Marine Scotland) }\end{array}$ \\
\hline Ireland & Tralee Bay Hatchery & $\begin{array}{l}\text { Hatchery and spatting } \\
\text { pond }\end{array}$ & unknown & No diseases & Irregular production \\
\hline Ireland & Cartron Point Shellfish & 10 spatting ponds & $\begin{array}{l}40.000-10 \text { million spat per } \\
\text { pond }\end{array}$ & Bonamia positive area & $\begin{array}{l}\text { Broodstock from Bonamia free } \\
\text { area (south and southwest of } \\
\text { Ireland). }\end{array}$ \\
\hline France & Novostrea Bretagne SAS & $\begin{array}{l}\text { Hatchery (from June- } \\
\text { October) }\end{array}$ & $\begin{array}{l}\text { Up to } 5 \text { million spat T2 per year } \\
\text { (if requested in time) }\end{array}$ & No diseases & $\begin{array}{l}\text { Started in } 2011 \text {, delivering spat } \\
\text { on shell and seed up to T2. } \\
\text { Histology analysis with } \\
\text { Labogena lab, takes } 3 \text { weeks. }\end{array}$ \\
\hline France & Ostrea Marinove SCEA & Hatchery & $\begin{array}{l}20 \text { million per year between } 1.5 \\
\text { and } 15 \mathrm{~mm}\end{array}$ & No diseases & $\begin{array}{l}\text { Tested several times per year } \\
\text { for diseases. Larger oysters not } \\
\text { certified Bonamia free because } \\
\text { in contact with environment. }\end{array}$ \\
\hline Portugal & AquaNostra & $\begin{array}{l}\text { Hatchery, first only } \\
\text { spat, later also adults. }\end{array}$ & $\begin{array}{l}\text { Annual production: } 100.000 \mathrm{~kg} \\
\text { in pond farm, } 300.000 \mathrm{~kg} \text { in } \\
\text { offshore farm. In numbers } 1.5 \\
\text { million adults }\end{array}$ & No diseases & $\begin{array}{l}\text { Started in } 2019 \text {. Testing of } \\
\text { Bonamia and Marteilia is done } \\
\text { every } 1 \text { or } 2 \text { months, } \\
\text { partnership with University of } \\
\text { Algarve, government is checking }\end{array}$ \\
\hline Spain & A Ostreira S.L. & Hatchery & $\begin{array}{l}\text { Best case scenario: up to } 2 \\
\text { million spat } \\
\text { Produced clams in } 2020\end{array}$ & $\begin{array}{l}\text { No diseases in the stock, } \\
\text { but in Bonamia positive } \\
\text { area }\end{array}$ & $\begin{array}{l}\text { Will start flat oyster production } \\
\text { again beginning of } 2021 \text {. } \\
\text { University of Santiago de } \\
\text { Compostela takes samples for } \\
\text { Bonamia check. }\end{array}$ \\
\hline
\end{tabular}




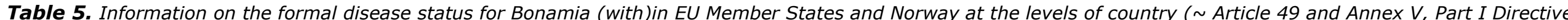

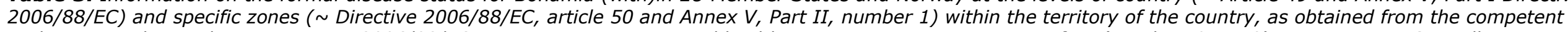

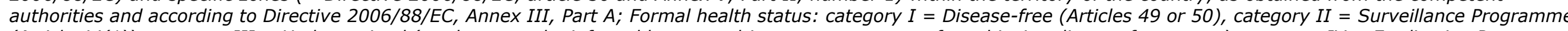

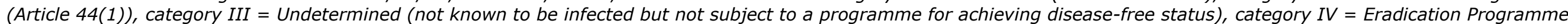
(Article 44(2)), category V = Infected (Article 39). Information compiled July to September 2020.

\begin{tabular}{|c|c|c|c|}
\hline Country & Zone(s) within the country & $\begin{array}{l}\text { Formal health } \\
\text { status }\end{array}$ & Comments \\
\hline \multicolumn{2}{|l|}{ Norway } & I & Except for the Arendal area \\
\hline & - Arendal & $I I$ & \\
\hline \multicolumn{2}{|l|}{ Sweden } & III & \\
\hline \multicolumn{2}{|l|}{ Denmark } & III & Except for the Limfjorden area \\
\hline & - Limfjorden & $V$ & \\
\hline Germany & & III & \\
\hline \multicolumn{2}{|l|}{ The Netherlands } & III & $\begin{array}{l}\text { Except for the following areas (not formally recognized as "zones"): Oosterschelde, } \\
\text { Grevelingen, where the presence of Bonamia has been assessed on a yearly basis and a } \\
\text { part of the Voordelta area where Bonamia presence has also been assessed }\end{array}$ \\
\hline \multicolumn{2}{|l|}{ Belgium } & III & \\
\hline \multicolumn{2}{|l|}{ Ireland } & I & Except for nine zones (see below) \\
\hline & - Cork Harbour & $V$ & \\
\hline & - Galway Bay & $V$ & \\
\hline & - Ballinakill Harbour & $V$ & \\
\hline & - Clew Bay & $V$ & \\
\hline & - Achill Sound & V & \\
\hline & - Loughmore, Blacksod Bay & $V$ & \\
\hline & - Lough Foyle & $V$ & \\
\hline & - Lough Swilly & $V$ & \\
\hline & - Kilkieran Bay & $V$ & \\
\hline & - Tralee Bay & $I$ & $\begin{array}{l}\text { Tralee Bay is a Bonamia-free zone and is currently sampled every second year at a level } \\
\text { of } 150 \text { oysters and screened by cytology for the presence of Bonamia sp. as specified in } \\
2015 / 1554 / \text { EC. }\end{array}$ \\
\hline
\end{tabular}




\begin{tabular}{|c|c|c|c|}
\hline \multicolumn{2}{|l|}{ UK England and Wales) } & I & Except for five zones (see below) \\
\hline & - Lizard to Start Point & $V$ & i.e., the south coast of Cornwall from the Lizard to Start Point \\
\hline & - Portland Bill to Selsey Bill & $V$ & i.e., the coast of Dorset, Hampshire and Sussex from Portland Bill to Selsey Bill \\
\hline & $\begin{array}{l}\text { - North Foreland to Landguard } \\
\text { Point }\end{array}$ & $V$ & i.e., the area along the coast of North Kent and Essex from North Foreland to Felixstowe \\
\hline & - St Ann's Head to Linney Head & 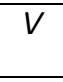 & $\begin{array}{l}\text { i.e., the area along the coast in south-west Wales from Wooltack Point to St Govan's } \\
\text { Head, including Milford Haven and the tidal waters of the East and West Cleddau river }\end{array}$ \\
\hline & - Menai Strait & $V$ & $\begin{array}{l}\text { i.e., the Menai Straits between Anglesey and Conwy in North West Wales between } \\
\text { Llandudno and Caernarfon Bay }\end{array}$ \\
\hline \multirow[t]{5}{*}{ UK (Scotland) } & & I & except for four zones \\
\hline & - West Loch Tarbert & $V$ & \\
\hline & - Loch Sunart & $V$ & \\
\hline & - Dornoch Firth & $V$ & \\
\hline & $\begin{array}{l}\text { - Sgeir liath, Loch Creran and } \\
\text { Loch Etive }\end{array}$ & $V$ & \\
\hline \multicolumn{2}{|l|}{ France } & III & $\begin{array}{l}\text { Individual French farms (hatcheries, spatting ponds, etc.) producing flat oysters can be } \\
\text { free of Bonamia, however we could not retrieve yet whether these have been formally } \\
\text { designated as compartments with a formal health status of 'disease-free'. }\end{array}$ \\
\hline \multicolumn{2}{|l|}{ Spain } & III & $\begin{array}{l}\text { In Galicia, Cataluña, Andalucía, Asturias and the Balearic Islands outbreaks of the disease } \\
\text { were detected in the past, however, currently the Spanish authorities have received no } \\
\text { notifications of unsolved abnormal mortalities in any of them. }\end{array}$ \\
\hline & $?$ & \\
\hline \multirow{5}{*}{ Portugal } & $\begin{array}{l}\text { - DSAVR Lisboa e Vale do Tejo/ } \\
\text { Aquacultura Texugo/ Sado } \\
\text { Estuary }\end{array}$ & $I I$ & Company name: Ostradamos/ 2067 \\
\hline & $\begin{array}{l}\text { - DSAVR Lisboa e Vale do Tejo/ } \\
\text { Sado Estuary }\end{array}$ & $I I$ & Company name: Marvellous Wave/ 1270 \\
\hline & $\begin{array}{l}\text { - DSAVR Lisboa e Vale do Tejo/ } \\
\text { Sado Estuary }\end{array}$ & $I I$ & Company name: Marvellous Wave/ 1270 \\
\hline & - DSAVR Algarve/ Ria de Alvor & III & \\
\hline & - DSAVR Algarve/ Ria Formosa & $I I I$ & \\
\hline
\end{tabular}


In this chapter the advantages and disadvantages of the available methods to produce or acquire flat oysters with the right quality are discussed as well as options and recommendations to reach the demand.

\subsection{Options to reach the demand of starting material}

Table 6 gives an overview of the advantages and disadvantages of options for European flat oyster supply for restoration projects in Dutch North Sea. From this overview it can be concluded that all options have advantages and disadvantages. When looking at the disadvantages hatchery production has the lowest risks. Acquisition of all starting material requires planning. This is outlined below for the different life stages. 
Table 6. Advantages and disadvantages of options for European flat oyster supply for restoration projects in Dutch North Sea.

\begin{tabular}{|c|c|c|c|}
\hline Option & Advantage & Disadvantage / risk & Contingency plan \\
\hline \multirow{5}{*}{$\begin{array}{l}\text { Collection of } \\
\text { adults }\end{array}$} & $\begin{array}{l}\text { Possibility of larval } \\
\text { production starting from } \\
\text { the first year of } \\
\text { restoration project }\end{array}$ & $\begin{array}{l}\text { Need males and females for } \\
\text { reproduction }\end{array}$ & $\begin{array}{l}\text { Starting population must } \\
\text { contain different sizes to } \\
\text { ensure presence of both sexes. }\end{array}$ \\
\hline & High genetic diversity & No risk & \\
\hline & & $\begin{array}{l}\text { Possibility of alien species } \\
\text { attached to the shells and } \\
\text { inside mantle cavity }\end{array}$ & $\begin{array}{l}\text { Treatment needed to remove } \\
\text { alien species attached to the } \\
\text { shells and inside mantle cavity } \\
\text { This is available, but a } \\
\text { potential risk cannot be } 100 \% \\
\text { eliminated. }\end{array}$ \\
\hline & & $\begin{array}{l}\text { Size of source population is } \\
\text { reduced }\end{array}$ & Management of natural bed \\
\hline & & Oysters may carry pathogens & $\begin{array}{l}\text { Only oysters allowed from } \\
\text { disease-free areas }\end{array}$ \\
\hline \multirow{5}{*}{$\begin{array}{l}\text { Spat collection } \\
\text { in ponds or in } \\
\text { field }\end{array}$} & $\begin{array}{l}\text { No reduction of source } \\
\text { population }\end{array}$ & No risk & \\
\hline & $\begin{array}{l}\text { Moderate genetic } \\
\text { diversity }\end{array}$ & Moderate risk of inbreeding & $\begin{array}{l}\text { Use spat from different } \\
\text { locations and spatting ponds }\end{array}$ \\
\hline & & $\begin{array}{l}\text { Possibility of alien species } \\
\text { attached to the shells and } \\
\text { inside mantle cavity }\end{array}$ & $\begin{array}{l}\text { Treatment needed to } \\
\text { potentially remove alien } \\
\text { species, is not available yet }\end{array}$ \\
\hline & & $\begin{array}{l}\text { Settlement only once a year } \\
\text { and irregular between years }\end{array}$ & $\begin{array}{l}\text { Use spat from different } \\
\text { locations and spatting ponds }\end{array}$ \\
\hline & & Oysters may carry pathogens & $\begin{array}{l}\text { Only oysters allowed from } \\
\text { disease-free areas and ponds }\end{array}$ \\
\hline \multirow{5}{*}{$\begin{array}{l}\text { Hatchery } \\
\text { production }\end{array}$} & $\begin{array}{l}\text { No reduction of source } \\
\text { population }\end{array}$ & No risk & \\
\hline & No treatment needed & No risk & \\
\hline & $\begin{array}{l}\text { Production of disease } \\
\text { resistant/tolerant } \\
\text { oysters }\end{array}$ & $\begin{array}{l}\text { Method is under development } \\
\text { (see } 5.1 .3 \text { ) and first results are } \\
\text { promising }\end{array}$ & Continue development \\
\hline & & $\begin{array}{l}\text { Supply is limited, in part due } \\
\text { to current technical bottle } \\
\text { necks in production }\end{array}$ & $\begin{array}{l}\text { Carry out research on solving } \\
\text { the bottle necks }\end{array}$ \\
\hline & Low genetic diversity & Risk of inbreeding & $\begin{array}{l}\text { Use spat from different } \\
\text { broodstocks }\end{array}$ \\
\hline
\end{tabular}




\subsubsection{Adult oysters}

To import adult oysters from abroad a permit from the Netherlands Food and Consumer Product Safety Authority (NWVA) is needed. In addition, depending on the location of the pilot, a permit or exemption on basis of the Dutch Nature Conservation Act is needed when oysters are to be released in or in the vicinity of a marine Natura 2000 area. Shellfish transports, including transports of adult flat oysters, which were collected or grown in the open sea, can unintentionally introduce invasive alien species in new areas (Wolff, 2005). Invasions by invasive alien species can have a negative impact on native marine species and aquaculture (e.g., Thomsen et al., 2015). Applications for a permit must be accompanied by a risks assessment to estimate the risk of introduction, transport, spread and impact of invasive alien species. In Dutch risk assessments only invasive alien species, which are not yet established in the import area (cf. Wijsman et al., 2007) are assessed. For imports of shellfish to the Netherlands (usually blue mussels) surveys of shellfish-dependent species (SASI), which could be introduced with shellfish transports, are regularly carried out in export areas. Relevant SASI's are available for Morecambe Bay, England (Gittenberger et al., 2017); L'Epine, Baie de Bourgneuf, France (Gittenberger et al., 2018a); Limfjord, Denmark (Gittenberger et al., 2018b); Tralee Bay, Ireland (Gittenberger et all, 2018c); Sweden (Gittenberger et al., 2018d). Organisms attached to the shell, such as macroalgae, or organisms present in the shell cavity, such as toxic microalgae, or organisms living in the animal, such as the parasite Bonamia can all be spread through transport (Brenner et al., 2014). Therefore, only adults from disease free areas should be used. This can be established by contacting the producer or the National Reference Laboratory. To minimise the risk further a treatment protocol a was developed for oysters from Norway with which the organisms on the shell and in the shell cavity are removed (van der Have et al., 2018); van den Brink \& Magnesen 2018).

This involves:

1. Manually inspect oysters from the field to remove any other large and obvious organisms.

2. Tumble $20 \mathrm{~kg}$ of oysters in $30 \mathrm{~L}$ of freshwater (or so that oysters are submerged when stationary) for 5-7 minutes in a cement mixer.

3. Leave oysters in running seawater for $3+$ days to allow them to recover and reseal their shells after damage from the tumbling process.

4. Submerge oysters in freshwater, then add $5 \mathrm{ml} \mathrm{p} \mathrm{L} \mathrm{of} 15 \%$ laboratory grade sodium hypochlorite for 15-20 minutes.

5. Wash oysters in freshwater to remove sodium hypochlorite and any loose, dead epibionts.

Recommendations

- Treat and transport oysters in winter to minimise initial amount of epibiota growth.

- Do not exceed the recommended relative amount of oysters in the cement mixer. If there are too many oysters, it will reduce the effectiveness of the tumbling.

- Prior to exposure to chlorine, submerge or physically jolt the oysters so that they close to prevent chlorine uptake.

- During submersion in the chlorine, make sure the oysters are well spaced so that the chemical has optimal access to the whole surface area of the oyster.

A quarantine system is needed to remove microbial contaminants. Quarantine systems are closed systems, or systems where water is purified before it is drained. A quarantine period of a few weeks in combination with a monitoring program on the effluent water and shellfish reduces the risk of species introduction (Norton et al., 1993). However, a quarantine system will not remove all the fouling organisms on the oysters. For that, the above mentioned a treatment protocol was established. In the case of the Norwegian oysters, after they were treated the oysters were kept in filtered running seawater in Norway for two weeks prior to shipment to the Netherlands. This treatment removed organisms in the mantle cavity. 


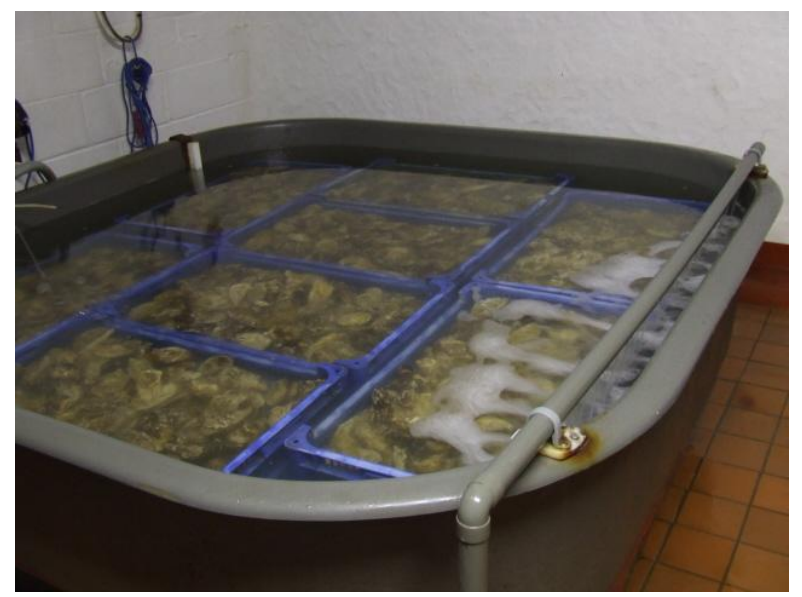

Figure 22. Quarantine system (picture Menai Oysters).

\subsubsection{Spat from field and ponds}

Natural settlement of flat oyster larvae onto substrates occurs in summer. Collection in the field is less predictable than in ponds as large settlements do not occur every year (Bromley et al., 2016). The substrates used to collect spat need to be free of attached organisms when they are introduced in the field. Mussel shells are generally cooked, which is an efficient way to remove fouling and pathogens. Oyster shells generally are fresh when they become available. Thus, a weathering period of at least a few months is needed. This involves placing the shells outdoors to allow the elements including rain, sun and bacterial processes to break down any remaining tissue and potential disease organisms and alien species. The process usually takes place over 6-12 months, however, if active cleaning such as cooking is involved the period can be significantly reduced. Spat collectors do not only collect spat, but also fouling organisms. When transported from an area outside the Dutch North Sea the same rules apply as for adult oysters, i.e. a risk assessment for invasive alien species and a treatment to remove epibionts. At present, there is no experience with the use of the treatment protocol for flat oyster spat. Most probably an adjustment is needed, given the fact that spat is much more vulnerable that adults.

\subsubsection{Hatchery spat}

Hatchery production can be year round in theory, but no hatchery has accomplished that as yet. The main larval production season is April to September. In a hatchery, spat is produced as single oysters for consumption. For this, very small pieces of substrate called cultch, is used. For restoration projects larger substrate, such as complete shells can be used (Figure 23). These shells need to be cleaned as described above. When so called spat on shell is used, a nursery phase is not needed. The recently settled oysters can be transferred to the pilot site directly. This removes the risk of fouling with alien species during rearing in an outdoor nursery. For flat oysters there is not much experience with outplacement of spat on shell, but the first results are promising (https://www.naturetoday.com/intl/nl/naturereports/message/?utm_source=newsletter\&utm_medium=e-mail\&utm_campaign=usermailing\&msg=25371). Of the hatcheries listed in Table 4, only Roem van Yerseke is presently producing flat oyster spat on shell, but other hatcheries are willing to produce it when the demand is there. 


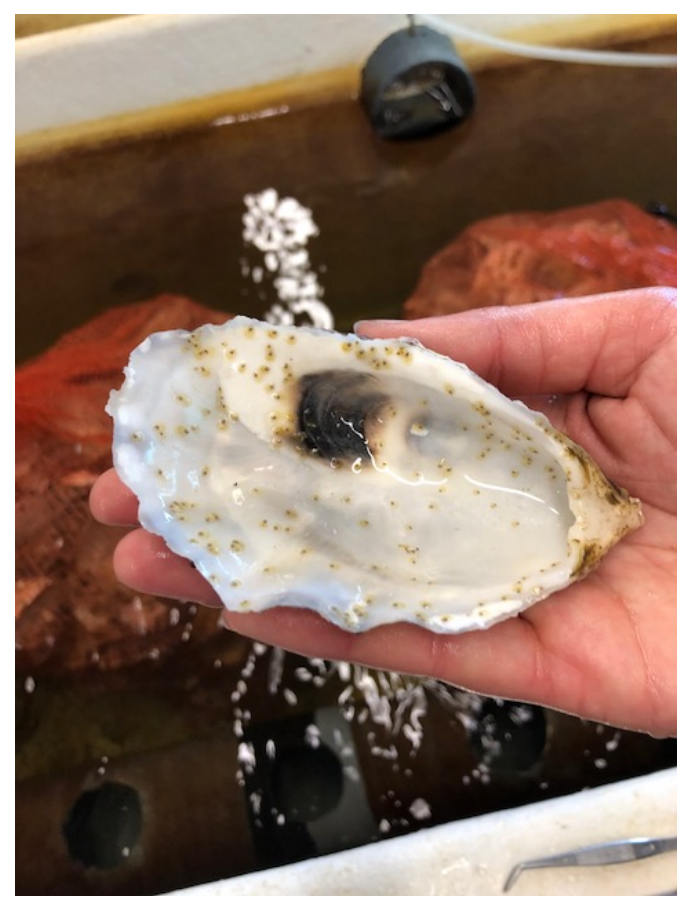

Figure 23. Pacific oyster shell with flat oyster spat (small yellow dots) at hatchery Roem van Yerseke (picture Ainhoa Blanco).

\section{Genetic diversity}

Lallias et al. (2010) compared the genetic variation in flat oysters from hatchery sources, pondcultured sources and wild sources. They found that hatchery produced-populations showed a loss of genetic diversity compared to wild populations and pond-cultured oysters were intermediate. From a genetic point of view pond production is recommended by Lallias et al. (2010) for flat oyster restoration as ponds are more efficient in maintaining genetic diversity. However, management of genetic diversity in a hatchery through smart selection of broodstock is an option (Ryman \& Laikre, 1991).

\section{Bonamia-free spat}

As described above transfer of diseases to new areas should be prevented. A number of hatcheries are located in Bonamia-free areas and produce Bonamia-free spat (Table 4). In addition, a novel, nondestructive screening method to determine the status of the oyster with regard to Bonamia was developed (Kamermans et al., submitted). With this method Bonamia-free oysters were selected from a Bonamia infected population. These oysters produced Bonamia-free larvae and spat. In this way, a Bonamia-free broodstock can be established in a hatchery that produces Bonamia-free offspring. Producing Bonamia-free oysters with broodstock originating from a Bonamia-infected area provides disease-free oysters. Presently is it investigated if these oysters have developed tolerance or resistance to the disease. This is very useful for restoration projects since protection against disease, through tolerance or resistance, is desired, in case it does appear in a newly established bed. For a hatchery to become formally recognised as disease free under EU Directive 2006/88/EC (on animal health requirements for aquaculture animals and products thereof, and on the prevention and control of certain diseases in aquatic animals) it is needed to demonstrate that the hatchery has been disease free for at least 2 years (https://eur-

lex.europa.eu/LexUriServ/LexUriServ.do?uri=OJ:L:2006:328:0014:0056:en:PDF\%20). In addition, a monitoring programme must show that the hatchery remains disease free. When the disease is detected, the company loses its disease-free status.

\section{Costs of flat oyster hatchery for restoration projects}

Presently supply of flat oyster spat is limiting and mainly aimed at consumption. Therefore, given the expected increasing demand for flat oysters for nature restoration purposes, there may be opportunities for new hatcheries. In this paragraph a rough estimation of the costs involved in setting up and running a hatchery is presented (based on Veenstra et al., 2008 and van Dalen et al, 
unpublished data). It is assumed that the hatchery will produce spat on shell (or on other substrates) and that an outdoor nursery phase is not needed, because the spat can be transferred to the field at a size of about $2 \mathrm{~mm}$. In addition, the customer will have to arrange transport of the spat to the restoration pilot. Table 7 shows that the investment costs are approximately $€ 580,000$ and table 8shows that the running costs are around $€ 530,000$ per year.

Table 7. The investment costs for a flat oyster hatchery for 10 million spat $2 \mathrm{~mm}$.

\begin{tabular}{|l|r|}
\hline Items & Costs \\
\hline Site development costs & $€ 10,000$ \\
\hline Building & $€ 300,000$ \\
\hline Water system: pumping and treatment & $€ 10,000$ \\
\hline Networks & $€ 2,000$ \\
\hline Heating system & $€ 12,000$ \\
\hline Algae production & $€ 150,000$ \\
\hline Blowers & $€ 3,000$ \\
\hline Wet Lab & $€ 3,000$ \\
\hline Office, store room, toilet & $€ 2,000$ \\
\hline Total for buildings, equipment, & $€ 500,000$ \\
\hline infrastructure & $€ 50,000$ \\
\hline Contingencies (10\%) & $€ 20,000$ \\
\hline Detailed design work & $€ 10,000$ \\
\hline legalities, permits, inspections & \\
\hline & $\mathbf{5 8 0 , 0 0 0}$ \\
\hline Grand Total & \\
\hline
\end{tabular}


Table 8. The yearly operational costs for an oyster hatchery for 10 million spat $2 \mathrm{~mm}$.

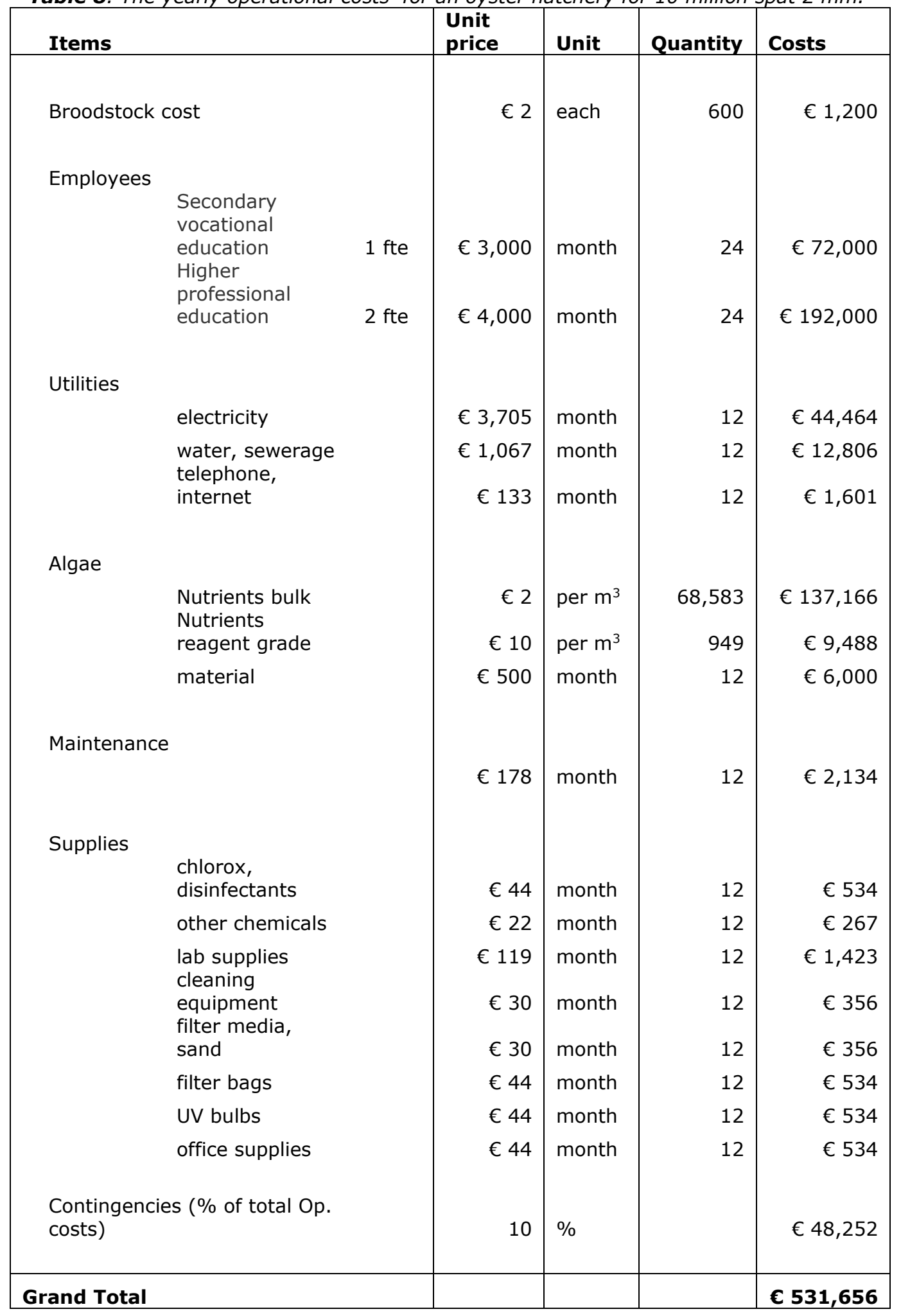

\subsection{Recommendations}

- Source material for flat oyster restoration projects is available as adult oysters, spat collected in the field or produced in ponds and hatcheries.

- When taking the right precautions, these oysters can be disease free, without non-native species and with sufficient genetic diversity.

- Production of spat on shell in a hatchery provides the source with the lowest risks to the environment. This is the recommended source.

- Genetic diversity can be critical in hatchery production. Therefore, the use of spat from different hatcheries is advised. 
- Around 12 months is needed to obtain the required permits, order shell and set spat on that shell in a hatchery.

- $\quad$ Spat on shell needs to be introduced for at least 3 consecutive years to build up a population consisting of males and females.

- $\quad$ There is limited experience with outplacement of flat oyster spat on shell at restoration locations. Therefore, research to optimise this method is recommended (determine most effective spat size and most effective outplacement period).

- Furthermore, a research programme adjacent to hatchery development is recommended to tackle the current bottle necks in flat oyster hatchery production (sudden mortalities of larvae, reduced survival during metamorphosis, low genetic diversity, disease susceptibility). 


\section{Acknowledgements}

We would like to thank the flat oyster hatchery and pond producers in Atlantic Europe for providing information for table 4 and the following persons for providing information for table 5 :

- Odd Arne Brimsø (Norway)

- Jenny Kanerva Eriksson (Sweden)

- Torben Grubbe (Denmark)

- Alexander Heinrich (Germany)

- Gieta Mahabir and Marc Engelsma (the Netherlands)

- Chantal Rettigner (Belgium)

- Michael Gubbins (UK - England and Wales)

- Andrea Warwick (UK- Scotland)

- Deborah Cheslett (Ireland)

- Clémence Bourély (France)

- Ines Moreno (Spain)

- Susana Freitas (Portugal) 


\section{Quality Assurance}

Wageningen Marine Research utilises an ISO 9001:2015 certified quality management system. This certificate is valid until 15 December 2021. The organisation has been certified since 27 February 2001. The certification was issued by DNV GL. 


\section{References}

Araya, R.A., Jorquera, M.A., Riquelme, C.E., 1999. Asociación de bacterias al ciclo de vida de Argopecten purpuratus. Revista Chilena de Historia Natural 72, 261-271

Baggett, L.P., S.P. Powers, R. Brumbaugh, L.D. Coen, B. DeAngelis, J. Greene, B. Hancock, and S. Morlock, 2014. Oyster habitat restoration monitoring and assessment handbook. The Nature Conservancy, Arlington, VA, USA, 96pp.

Baud, J.P., Gérard, Y. Naciri-Graven (1997). Comparative growth and mortality of Bonamia ostreaeresistant and wild flat oysters, Ostrea edulis, in an intensive system. I. First year of experiment. Mar. Biol. 130: 71-79.

Beck MW, Brumbaugh RD, Airoldi L, Carranza A, Coen LD, Crawford C et al. (2011) Oyster Reefs at Risk and Recommendations for Conservation, Restoration, and Management. Bioscience. 61:107116. doi:10.1525/bio.2011.61.2.5.

Berghahn, R., and M. Ruth. 2005. The disappearance of oysters from the Wadden Sea: A cautionary tale for no-take zones. Aquatic Conservation: Marine and Freshwater Ecosystems 15:91-104.

Bodoy, A., S. Bougrier, P. Geairon, J. Garnier, V. Boulo and S. Heurtebise, 1991: "Does the prevalence of Bonamia and Marteilia diseases be reduced on flat oysters (Ostrea edulis) of Atlantic and Mediterranean origin, when they are reared together with the Japanese oyster (Crassostrea gigas) in tidal ponds?" ICES C.M. 28: 1-9.

Bouma TJ, S Olenin, K Reise, T Ysebaert. 2009. Ecosystem engineering and biodiversity in coastal sediments: posing hypotheses. Helgoland Marine Research 63: 95-106.

Brenner, M., D. Fraser, K. Van Nieuwenhove, F. O`Beirn, B. H. Buck, J. Mazurié, G. Thorarinsdottir, P. Dolmer, A. Sanchez-Mata, O. Strand, G. Flimlin, L. Miossec, P. Kamermans (2014). Bivalve aquaculture transfers in Atlantic Europe. Part B: environmental impacts of transfer activities. Ocean and Coastal Management 89: 139-146

Brown C, Tettelbach LP (1988) Characterization of a nonmotile Vibrio sp. pathogenic to larvae of Mercenaria mercenaria and Crassostrea virginica. Aquaculture 74, 195-204

Brumbaugh RD, Sorabella LA, Garcia CO, Goldsborough WJ, Wesson JA. (2000) Making a case for community-based oyster restoration: An example from Hampton Roads, Virginia, USA. Journal of Shellfish Research. 19:467-472.

Bruno, J.F., Stachowicz, J.J., Bertness, M.D., 2003. Inclusion of facilitation into ecological theory. Trends Ecol. Evol. 18, 119-125.

Christianen M.J.A., W. Lengkeek, J.H. Bergsma, J.W.P. Coolen, K. Didderen, M. Dorenbosch, F.M.F. Driessen, P. Kamermans, E. Reuchlin-Hugenholtz, H. Sas, A. Smaal, K.A. van den Wijngaard, T.M. van der Have (2018) Return of the native facilitated by the invasive? Population composition, substrate preferences, and epibenthic species richness of a recently discovered shellfish reef with native European flat oysters (Ostrea edulis) in the North Sea. Marine Biology Research https://doi.org/10.1080/17451000.2018.1498520

Culloty S.C., Cronin M.A., Mulcahy M.F., 2004. Potential resistance of a number of populations of the oyster Ostrea edulis to the parasite Bonamia ostreae. Aquaculture 237, 41-58.

De Smet, B., van Oevelen, van D., Vincx, M., Vanaverbeke, J., Soetaert, K. (2016). Lanice conchilega structures carbon flows in soft-bottom intertidal areas. Marine Ecology Progress Series, 552: 4760.

Diaz-Almela E, Boudry P, Launey S. Bonhomme F, Lapegue S 2004 Reduced female gene flow in the European flat oyster Ostrea edulis. J. Hered. 95: 510-516

Didderen K., P. Kamermans, W. Lengkeek (2018) Gemini wind far oyster pilot Results 2018. Bureau Waardenburg Rapport

Didderen K, Lengkeek W, Kamermans P, Deden B, Reuchlin-Hugenholtz E (2019a) Pilot to actively restore native oyster reefs in the North Sea (https://www.ark.eu/sites/default/files/media/Schelpdierbanken/Report_Borkumse_Stenen.pdf). BuWa. Report 19-013

Didderen K., T.M. van der Have, J.H. Bergsma, H. van der Jagt, W. Lengkeek, P. Kamermans, A. van den Brink, M. Maathuis, H. Sas (2019b) Shellfish bed restoration pilots Voordelta, Netherlands Annual report 2018, ARK Report 
Dolmer P, Hoffmann E. 2004. Østersfiskeri i Limfjorden-sammenligning af redskaber.Danmarks Fiskeriundersøgelser. 43 pages.

Dubert, J., Barja, J.L., Romalde, J.L., 2017. New insights into pathogenic Vibrios affecting bivalves in hatcheries: Present and Future Prospects. Frontiers in Microbiology 8:762

Engelsma, M.Y., Kerkhoff, S., Roozenburg, I., Haenen, O.L.M., Van Gool, A., Sistermans, W., Wijnhoven, S. \& Hummel, H. (2010). Epidemiology of Bonamia ostreae infecting European flat oysters Ostrea edulis from Lake Grevelingen, The Netherlands. Marine Ecology Progress Series 409: 131-142.

European Commission (2013). Interpretation manual of European Union habitats - EUR-28. European Commission, DG Environment, Nature ENV B.3; http://ec.europa.eu/environment/nature/legislation/habitatsdirective/docs/Int_Manual_EU28.pdf

Fariñas-Franco JM, Pearce B, Mair JM, Harries DB, MacPherson RC, Porter JS, Reimer PJ, Sanderson WG. 2018. Missing native oyster (Ostrea edulis L.) beds in a European Marine Protected Area: Should there be widespread restorative management? Biol Conserv 221: 293-311

Gercken \& Schmidt 2014. Current Status of the European Oyster (Ostrea edulis) and Possibilities for Restoration in the German North Sea 2014. BFN report

Gittenberger, A., Rensing, M., Schrieken, N. and H. Stegenga (2017) Schelpdier Afhankelijke Soorten Inventarisatie: SASI van de mosselen in Morecambe Bay, Verenigd Koninkrijk, juli 2017. I.o.v. Vereniging van Importeurs van Schelpdieren. GiMaRIS rapport 2017_27: 15 pp.

Gittenberger, A., Rensing, M., Wesdorp, K. H., Schrieken, N. and H. Stegenga (2018a) Schelpdier Afhankelijke Soorten Inventarisatie: SASI van de oesters bij Baie de Bourgneuf, Frankrijk, oktober 2018. I.o.v. Vereniging van Importeurs van Schelpdieren. GiMaRIS rapport 2018_65: 11 pp.

Gittenberger, A., Rensing, M., Schrieken, N. and H. Stegenga (2018b) Schelpdier Afhankelijke Soorten Inventarisatie: SASI van de oesters in de Limfjord, Denemarken, september 2018. I.o.v. Vereniging van Importeurs van Schelpdieren. GiMaRIS rapport 2018_63: 14 pp.

Gittenberger, A., Rensing, M., D'Hont, A. and H. Stegenga (2018c) Schelpdier Afhankelijke Soorten Inventarisatie: SASI van de oesters bij Tralee Bay, Ierland, juli 2018. I.o.v. Vereniging van Importeurs van Schelpdieren. GiMaRIS rapport 2018_39: 15 pp.

Gittenberger, A., Korthof, R.E.M, Wesdorp, K. H., Stegenga, H. and M. Rensing (2018d) Inventarisatie van de soortendiversiteit in tarra van mosselen uit Zweden, voorjaar 2018. I.o.v. Vereniging van Importeurs van Schelpdieren. GiMaRIS rapport 2018_19: 12 pp.

Gómez-León, J., Villamil, L., Salger, S.A., Sallum, R.H., Remacha-Triviño, A., Leavitt, D. F., GómezChiarri, M., 2008. Survival of eastern oysters Crassostrea virginica from three lines following experimental challenge with bacterial pathogens. Diseases of Aquatic Organisms 79, 95-105.

González-Araya R, Robert R (2018) Larval development and fatty acid composition of Ostrea edulis (L.) fed four different single diets from conditioning to pre-settlement. Aquaculture Research 49: 1768-1781.

Gravestock V, James F, Goulden M. 2014. Solent Native Oyster (Ostrea edulis) Restoration _ Literature Review \& Feasibility Study. MacAlister Elliott \& Partners, pp. 77.

Gutierrez AP, F Turner, K Gharbi, R Talbot, NR Lowe, C Peñaloza, M McCullough,PA Prodöhl, TP Bean, RD Houston (2017) Development of a medium density combined-species SNP Array for Pacific and European oysters (Crassostrea gigas and Ostrea edulis). G3 Genes Genomes Genetics 7: 22092218.

Haenen, O, M. Engelsma, S. van Beurden (2011) Ziekten van vissen, schaal-, en schelpdieren van belang voor de Nederlandse aquacultuur. CVI-WUR. ISBN 978-94-6190-101-9

Harding S, Nelson L, Glover T. 2016. Solent Oyster Restoration Project Management Plan. Blue Marine Foundation, pp. 47.

Hayward, P.J.; Ryland, J.S. Handbook of the Marine Fauna of North-West Europe; Oxford University Press: New York, NY, USA, 1998

Helm MM, Bourne N, Lovatelli A (2004) Hatchery culture of bivalves. A practical manual. FAO Fish. Tech. Pap., 471, 176.

Houziaux,J.-S., Kerckhof,F., Degrendele, K.,Roche, M. Norro A.,2008. The Hinder Banks Yet an important region for the Belgian marine biodiversity? Final report HINDERS project, Belgian Science Policy Office,pp.249. AvailableonlineatURL: /http://www.belspo.be/belspo/home/publ/pub_ostc/EV/rappEV45_en.pdfS.

Jackson, A. 2007. Ostrea edulis. Native oyster. Marine Life Information Network: Biology and Sensitivity Key Information Sub-programmem [on-line]. Marine Biological Association of the United Kingdom., Plymouth. 
Jordan-Cooley, WC, RN Lipcius, LB Shaw, J Shen, J Shi (2011) Bistability in a differential equation model of oyster population and sediment volume. Journal of Theoretical Biology 289: 1-11.

Joyce A, TD Holthuis, G Charrier and S Lindegarth (2013) Experimental Effects of Temperature and Photoperiod on Synchrony of Gametogenesis and Sex Ratio in the European Oyster Ostrea edulis (Linnaeus) Journal of Shellfish Research, 32(2):447-458.

Kamermans, P., E. Brummelhuis, K.J. Perdon, A.C.M. van Gool \& J. Poelman (2004). Verbetering broedval mosselen. RIVO Rapport C013/04.

Kamermans P, Van Duren L, Kleissen F (2018a) European flat oysters on offshore wind farms: additional locations : opportunities for the development of European flat oyster (Ostrea edulis) populations on planned wind farms and additional locations in the Dutch section of the North Sea (http://dx.doi.org/10.18174/456358). Wageningen Marine Research / Deltares. Report C053/18

Kamermans P., B. Walles, M. Kraan, L.A. van Duren, F. Kleissen \& T.M. van der Have, A.C. Smaal, M. Poelman (2018b) Offshore wind farms as potential locations for flat oyster (Ostrea edulis) restoration in the 1 Dutch North Sea. Sustainability 10, 3942; doi:10.3390/su10113942

Kamermans P, F Kleissen, L van Duren, M Engelsma (2018c) Begrenzing deel Voordelta als niet Bonamia - vrij gebied binnen de Nederlandse Noordzee. Wageningen University \& Research rapport $\mathrm{C} 112 / 18$

Kamermans P., B. Walles, M. Kraan, L.A. van Duren, F. Kleissen \& T.M. van der Have, A.C. Smaal, M.

Kellogg ML, Cornwell JC, Owens MS, Paynter KT (2013) Denitrification and nutrient assimilation on a restored oyster reef. Mar Ecol Prog Ser 480:1-19. https://doi.org/10.3354/meps10331

Kennedy RJ, Roberts D. (2006) Commercial oyster stocks as a potential source of larvae in the regeneration of Ostrea edulis in Strangford Lough, Northern Ireland. Journal of the Marine Biological Association of the United Kingdom. 86:153-159. doi:10.1017/s0025315406012963.

Korringa, P. 1954, The shells of Ostrea edulis as a habitat. Arch. Neerl. Zoöl. 10, 32-146.Laing I, P Walker and F Areal (2005) A feasibility study of native oyster (Ostrea edulis) stock regeneration in the United Kingdom CARD Project FC1016 Native Oyster Stock Regeneration - A Review of Biological, Technical and Economic Feasibility

Lallias, D., P, Boudry, S. Lapegue, J.W. Kin, A.R. Beaumont (2010) Strategies for the retention of high genetic variability in European flat oyster (Ostrea edulis) restoration programmes. Conserv Genet 11:1899-1910 DOI 10.1007/s10592-010-0081-0

Launey S, Barre M, Gerard A, Naciri-Graven Y (2001). Population bottleneck and effective size in Bonamia-ostreae-resistant populations of Ostrea edulis as inferred by microsatelite markers. Genetic Research 78: 259-270.

Launey S, Ledu C, Boudry P, Bonhomme F. Naciri-Graven Y 2002 Geographic structure in European flat oyster (Ostrea edulis L.) as revealed by microsattete polymorphism. J. Hered. 93: 40-47.

Lenihan, H. S., \& Peterson, C. H. (1998). How habitat degradation through fishery disturbance enhances impacts of hypoxia on oyster reefs. Ecological Applications, 8(1), 128-140.

Loosanoff V. 1962. Gametogenesis ans spawning of the European oyster, O. edulis, in waters of Maine. Biol. Bull. 122: 86-94.

Maathuis M. (2018) Shellfish bed restoration in the Voordelta (North Sea): Factors determining the timing of swarming of European flat oyster (Ostrea edulis) larvae and the efficiency of different shell substrates for collecting $O$. edulis spat. MSc Thesis University of Amsterdam.

Maathuis MAM, JWP Coolen, T van der Have, P Kamermans. (2020) Factors determining the timing of swarming of European flat oyster (Ostrea edulis L.) larvae in the Dutch Delta area: implications for flat oyster restoration. Journal of Sea Research156 https://doi.org/10.1016/j.seares.2019.101828

Maneiro V., Perez-Paralle M.L., Pazos A.J., Silva A., Sanchez J.L., 2016. Combined effects of temperature and photoperiod on the conditioning of the flat oyster (Ostrea edulis L.) in winter. Journal of Shellfish Research 35, 137-141

Maneiro V., Perez-Paralle M.L., Silva A., Sanchez J.L., Pazos A.J, 2017. Conditioning of the European flat oyster (Ostrea edulis, Linnaeus 1758): effect of food ration. Aquaculture Research 48, 43634370

Ministerie van Infrastructuur en Waterstaat en Ministerie van LNV [Min. IenW \& Min. LNV] (2018). Mariene Strategie (deel 1): actualisatie van huidige milieutoestand, goede milieutoestand, milieudoelen en indicatoren; 2018-2024 [Marine Strategy (part 1): update of current environmental status, good environmental status, environmental targets and indicators; 20182024]. Den Haag.

https://www.noordzeeloket.nl/publish/pages/151699/mariene_strategie_deel_1_actualisatie_2018 .pdf 
Montes J, A Villalba, M.C López, M.J Carballal, SG. Mourelle 1991 Bonamiasis in native flat oysters (Ostrea edulis L.) from two intertidal beds of the Ortigueira estuary (Galicia, N.W. Spain) with different histories of oyster culture Aquaculture 93: 213-224

Muus BJ, Dahlstr.om P. 1973. Meeresfische. BLV: Munchen.

Naciri-Graven, Y., Haure, J., Gerard, A., Baud, J.P. (1999). Comparative growth of Bonamia ostreae resistant and wild flat oyster Ostrea edulis in an intensive system - II. Second year of the experiment. Aquaculture 171: 195-208.

Naciri-Graven, Y., Martin, A.G., Baud, J.P., Renault, T., Gerard, A. (1998). Selecting the flat oyster Ostrea edulis (L) for survival when infected with the parasite Bonamia ostreae. J. Exp. Mar. Biol. Ecol. 224:91-107.

Newell, R. I. E. (2004). Ecosystem influences of natural and cultivated populations of suspensionfeeding bivalve molluscs: A review. Journal of Shellfish Research, 23, 51-61.

Norton J, Braley R, Anderson I (1993) A quarantine protocol to prevent the spread of parasitic diseases of giant clams (Tridacnidae) via translocation. In: ACIAR PROCEEDINGS. Australian Centre for International Agricultural Research, pp. 24-24.

O'Foighil, D. (1989) Role of spermatozeugmata in the spawning ecology of the brooding oyster Ostrea edulis. Gamete Research, 24: 219-228

Olsen, O. T. 1883. The piscatorial atlas of the North Sea, English and St. George's Channels. Grimsby, London.

OSPAR Commission (2008). OSPAR List of Threatened and/or Declining Species and Habitats. Reference Number: 2008-6. (http://www.ospar.org/documents?d=32794).

OSPAR Commission (2013). OSPAR Recommendation 2013/4 on furthering the protection and conservation of Ostrea edulis in Region II of the OSPAR maritime area and Ostrea edulis beds in Regions II, III and IV of the OSPAR maritime area. OSPAR(2) 13/4/1, Annex 7. https://www.ospar.org/documents?d=32968.

OYSTERECOVER (2013). Deliverable 15. Report identifying and describing best performing populations.

Puls, W., and Sündermann, J. (1990). Simulation of Suspended Sediment Dispersion in the North Sea. In "Residual Currents and Long-term Transport. Coastal and Estuarine Studies", Vol. 38.

Pogoda B. 2019. Current status of European oyster decline and restoration in Germany. Humanities 8 : 9.

Prado, S., Romalde, J.L., Montes, J., Barja, J.L., 2005. Pathogenic bacteria isolated from disease outbreaks in shellfish hatcheries. First description of Vibrio neptunius as an oyster pathogen. Diseases of Aquatic Organisms 67, 209-215

Reise, K.; Beusekom, J.E.E. 2008 Interactive effects of global and regional change on a coastal ecosystem. Helgol. Mar. Res., 62, 85-91.

Robert, R., Vignier, J., Petton, B., 2017. Influence of feeding and temperature on development and settlement of oyster Ostrea edulis (Lineaeus 1758) larvae. Aquaculture Research, 1-18

Rodriguez-Perez A, James M, Donnan DW, Henry TB, Møller LF, Sanderson WG. 2019. Conservation and restoration of a keystone species: understanding the settlement preferences of the European oyster (Ostrea edulis). Mar Pollut Bull 138: 312-321.

Ryman N, L. Laikre (1991) Effects of supportive breeding on the genetically effective population size. Conserv Biol 5: 325-329.

Sas, H., Kamermans, P., van der Have, T., Lengkeek, W. \& Smaal, A. 2016. Shellfish reef restoration pilots: Voordelta The Netherlands, Annual report 2016.

Sas H., P. Kamermans, T. van der Have, M. Christianen et al (2018) Shellfish reef restoration pilots Voordelta The Netherlands, Annual report 2017.

Sas H, K Didderen, T van der Have, P Kamermans, K van den Wijngaard, E Reuchlin (2019) Recommendations for flat oyster restoration in the North Sea Synthesis of lessons learned from the Dutch Voordelta experiments, with additional observations from flat oyster pilots in Borkum Reef and Gemini wind farm, modelling exercises and literature. ARK report

Sas H, B Deden, P Kamermans, PSE zu Ermgassen, B Pogoda, J Preston, L Helmer, Z Holbrook, I Arzul, T van der Have, A Villalba, B Colsoul, V Merk, A Lown, N Zwerschke, E Reuchlin. (2020) Bonamia infection in flat oysters (Ostrea edulis) in relation to European restoration projects. Accepted by Aquatic Conservation: Marine and Freshwater Ecosystems (NORA special issue)

Shelmerdine RL, Leslie B. 2009. Restocking of the native oyster, Ostrea edulis, in Shetland: habitat identification study. pp. 26. 
Smaal AC, P. Kamermans, T.M. van der Have, M. Engelsma \& H.J.W.Sas (2015) Feasibility of Flat Oyster (Ostrea edulis L.) restoration in the Dutch part of the North Sea. IMARES Report C028/15

Smaal, A; Kamermans, P; Kleissen, F; Duren, L van; Have, T van der (2017) Flat oysters on offshore wind farms : opportunities for the development of flat oyster populations on existing and planned wind farms in the Dutch section of the North Sea. Yerseke : Wageningen Marine Research, (Wageningen Marine Research report C052/17) - 53

Smyth, D., Roberts, D. (2010). The European oyster (Ostrea edulis) and its epibiotic succession. Hydrobiologia 655: 25-36

Sobolewska H. \& Beaumont A.R., 2005 Genetic variation at microsatelitte loci in northern populations of the European flat oyster (Ostrea edulis). J. Mar. Biol. Ass. U.K. 85: 955-960.

Thomsen, M.S., Wernberg, T. \& D. Schiel. 2015. Invasions by non-indigenous species. In: Marine ecosystems: Human impacts $\mathrm{n}$ biodiversity, ecosystem functioning and services. Crowe, T.P. \& C.L.J. Frid (eds.). Cambridge University Press, p. 274-331.

Thurstan RH, Hawkins JP, Raby L, Roberts CM. 2013. Oyster (Ostrea edulis) extirpation and ecosystem transformation in the Firth of Forth, Scotland. J Nat Conserv 21: 253-261.

Van Banning, P. (1982). Some aspects of the occurrence, importance and control of the oyster pathogen Bonamia ostreae in the Dutch oyster culture. Invertebrate pathology and microbial control: proceedings: IIIrd International Colloquium on Invertebrate Pathology and XVth Annual Meeting of the Society for Invertebrate Pathology, September 6-10, 1982 University of Sussex, pp. 243-245. United Kingdom: Brighton.

Van Banning, P. (1991). Observations on bonamiasis in the stock of the European flat oyster, Ostrea edulis, in the Netherlands, with special reference to the recent developments in Lake Grevelingen. Aquaculture 93: 205-211.

Van den Brink A, Fomsgaard C, Nédélec M, Mathieu Hussenot M, Kamermans P (2013) OYSTERECOVER: Testing the efficiency of different Spat Collectors IMARES Report number C216/13

Van den Brink A. \& T. Magnesen (2018) Follow-up test 'treatment protocol flat oysters' with Norwegian oysters. Memo Wageningen Marine Research

van den Brink AM, MAM Maathuis, P Kamermans. (2020) Can off-bottom spat collectors optimise restoration and production of the European flat oyster (Ostrea edulis) in Dutch coastal waters? Accepted by Aquatic Conservation: Marine and Freshwater Ecosystems. (NORA special issue)

Van der Have, T.M., P. Kamermans, E. van der Zee., 2017. Flat oysters in the Eijerlandse Gat, Wadden Sea. Results of a survey in 2017 Bureau Waardenburg Rapportnr. 17-231.

Van der Have T.M., M. Schutter, P. Kamermans, A. van den Brink (2018) Treatment protocol flat oysters Memo Bureau Waardenburg

Van der Heide, T., Tielens, E., van der Zee, E. M., Weerman, E. J., Holthuijsen, S., Eriksson, B. K., Piersma, T., van de Koppel, J., and Olff, H. (2014). Predation and habitat modification synergistically interact to control bivalve recruitment on intertidal mudflats. Biological Conservation 172, 163-169.

Van Oevelen D., Duineveld G., Lavaleye M., Mienis F., Soetaert K., Heip C.H.R. (2009) The cold-water coral community as a hot spot for carbon cycling on continental margins: A food-web analysis from Rockall Bank (northeast Atlantic). Limnology and Oceanography, 54(6), 1829-1844.

Van der Zee, E., T. Heide, S. Donadi, J. Eklöf, B. Eriksson, H. Olff, H. Veer, and T. Piersma. 2012. Spatially extended habitat modification by intertidal reef-building bivalves has implications for consumer-resource interactions. Ecosystems 15: 664-673.

Veenstra F, P Kamermans, M Poelman, P Geijsen, A Pronker, F Peene, R de Vos, H van Geesbergen (2008) SHANGO BUSINESSPLAN Gecontroleerd schelpdier-kweeksysteem, van zaad tot aan consumptiemossel. Systeemontwerp, protocollen, technisch-economische haalbaarheid. Wageningen IMARES Rapport C065/08

Walne, P.R. (1974). Culture of bivalve molluscs; 50 years of experience at Conwy. Fishing News Books Ltd, Farnham-Surrey-England, 189 pp.

Wieczorek, S. K., Todd, C. D., 1998. Inhibition and facilitation of settlement of epifaunal marine invertebrate larvae by microbial biofilm cues. Biofouling 12, 81-118

Wijsman, J.W.M., Tamis, J.E., Kaag, N.H.B.M., Karman, C.C., Foekema, E.M. \& A.C. Smaal. 2007. Risk analysis on the import of seed mussels from Norway into the Wadden Sea. Wageningen IMARES report nr. C102/07, Wageningen.

Wolff, W.J. 2005. Non-indigenous marine and estuarine species in The Netherlands. Zoologische Mededelingen Leiden 79: 1-116. 
Woolmer AP, Syvret M, FitzGerald A. 2011. Restoration of Native Oyster, Ostrea edulis, in South Wales.

zu Ermgassen, P.S.E., B. Hancock, B. DeAngelis, J. Greene, E. Schuster, M. Spalding, and R. Brumbaugh, 2016a. Setting objectives for oyster habitat restoration using ecosystem services: a manager's guide. TNC, Arlington VA. 76pp.

zu Ermgassen, P. S. E., Grabowski, J. H., Gair, J. R. and Powers, S. P. 2016b. Quantifying fish and mobile invertebrate production from a threatened nursery habitat. J Appl Ecol, 53: 596-606.

Yonge, C.M. 1960 Oysters. The New Naturalist, Collins, London, p.209

Ysebaert, T., Hart, M., and Herman, P. M. J. (2009). Impacts of bottom and suspended cultures of mussels Mytilus spp. on the surrounding sedimentary environment and macrobenthic biodiversity. Helgoland Marine Research 63, 59-74.

Zwerschke, N., Emmerson, M.C., Roberts, D., O'Connor, N.E., 2016. Benthic assemblages associated with native and non-native oysters are similar. Marine Pollution Bulletin, 111: 305-310. 


\section{Justification}

Report C085/20

Project Number: 4318100209-B3

The scientific quality of this report has been peer reviewed by a colleague scientist and a member of the Management Team of Wageningen Marine Research

Approved: $\quad$ Oscar Bos

Signature:

Date:

5 October 2020

Approved: Dr. J. Asjes

Manager Integration

Signature:

Date:

5 October 2020 
Wageningen Marine Research

$\mathrm{T}+31(0) 317480900$

E: marine-research@wur.nl www.wur.eu/marine-research

Visitors' address

- Ankerpark 271781 AG Den Helder

- Korringaweg 7, 4401 NT Yerseke

- Haringkade 1, 1976 CP IJmuiden
With knowledge, independent scientific research and advice, Wageningen Marine Research substantially contributes to more sustainable and more careful management, use and protection of natural riches in marine, coastal and freshwater areas.

Wageningen Marine Research is part of Wageningen University \& Research. Wageningen University \& Research is the collaboration between Wageningen University and the Wageningen Research Foundation and its mission is: 'To explore the potential for improving the quality of life' 